\title{
A deterministic seismic risk macrozonation of Seville
}

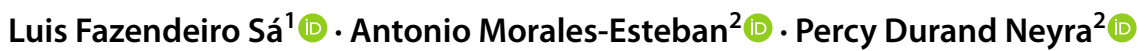

Received: 15 April 2021 / Accepted: 13 October 2021 / Published online: 10 November 2021

(c) The Author(s) 2021, corrected publication 2022

\begin{abstract}
The seismicity of the southwestern Iberian Peninsula is moderate but large events with long return periods occur $(\approx 200$ years). This exceeds the life of various generations, making the population unacquainted with the seismic hazard. On the one hand, this results in a low demanding seismic code which increases the seismic vulnerability and, therefore, the seismic risk. On the other hand, the local emergency services must be properly prepared to face a destructive seismic event, with emergency plans and mitigation strategies. This assumption enhances the need of assessing the seismic risk of Seville in a civil protection context. For all the aforementioned and for the lack of instrumental data of relevant earthquakes, the assessment of the seismic hazard in this area is challenging. To do this, seismogenic zones of the new seismic hazard map of Spain have been used as sources. The peak ground acceleration (PGA) for each scenario has been calculated by means of ground motion prediction equations (GMPE). To estimate the site effects, in a 1D model environment, a shear wave velocity (Vs) map of the top $5 \mathrm{~m}$ has been depicted based on the standard penetration test (SPT). Seville's building stock has been classified in agreement with the previous works in Lorca and Barcelona to determine its vulnerability. The main goal of this work was to investigate the influence of the soil amplification on the seismic behaviour of different building typologies. Therefore, the final target was to plot the damage scenarios expected in Seville under a maximum credible earthquake by means of a deterministic seismic hazard assessment (DSHA). As outputs, the scenario modelled showed that around 27000 buildings would experience a moderate damage and that 26000 would suffer pre-collapse or even collapse. Thus, approximately $10 \%$ of the population would lose their dwellings. Regarding the human loses, around 22000 people would suffer serious injuries and approximately 5000 people would die. Owing to these conclusions, this research evidences the crucial need by civil protection services to implement a local emergency plan as a tool to mitigate the probable consequences that arise from this threat.
\end{abstract}

Keywords Building vulnerability $\cdot$ Risk assessment $\cdot$ Seismicity $\cdot$ Emergency planning

Responsible Editor: Longjun Dong

Luis Fazendeiro Sá

luis.sa@prociv.pt

Antonio Morales-Esteban

ame@us.es

Percy Durand Neyra

percy@us.es

1 Department of Emergency Planning National, Portuguese National Authority for Civil Protection, Carnaxide, Portugal

2 Department of Building Structures and Geotechnical Engineering, University of Seville, Seville, Spain

\section{Introduction}

In Iberia, the regional seismicity is a product of the earthquake activity that is produced by the contact region of the Euro-Asian and the African tectonic plates and from the activity in the continental margin crossed by diverse local faults. This geological framework generates medium to large events with long return periods. This is a return period that exceeds a generation's lifespan. This is one of the reasons why some authors advocate that there is little awareness of the potential seismic risk in Andalusia (Garrido and Gutiérrez 2015). Indeed, seismic risk, besides analytically being considered as function of the spatial and temporal evolution of earthquake dynamics (including the focal mechanism), is to some extent also sociologically linked with awareness and perception. Scholars tend to agree that only in places where an event occurred within one or two generations 
there is memory and it is easier to find high building code enforcement, good design and construction practices. That was not the case of Seville. The last large earthquake felt in Seville with an intensity (MMI) $\geq \mathrm{VI}$ - assuming that damage to buildings and human live occurs with intensities (MMI) equal or superior to VI - happened in 1858, the Setúbal earthquake, November 1858, Mw 7.1 (Martínez Solares and Mezcua 2002). This result in those present generations does not have any memory of an event of this magnitude; thus they do not prepare for its occurrence. The lack of preparation can induce itself a low quality for existent building codes (Jaramillo 2009). In fact, the performance of buildings, especially those which are highly important, significantly suffer during critical situations. Thus, it could be claimed that the safety and resistance of structures faced with various hazards are crucial for the economy and industrial improvement. Unfortunately, the majority of buildings are deteriorating under environmental severe loads and insufficient maintenance. In some cases, the deficiency of buildings is hidden until the occurrence of a hazard (Alimohammadi et al. 2020). However, adopting and enforcing the latest building codes is only part of the solution. The other part, the preparation of an adequate response from the civil protection system to a disaster, is a responsibility of the local governments. In fact, nondependent of the measured threats, disaster risk management is an essential support to guarantee system sustainability because disregarding the growing risk - due to new exposed assets - makes the condition unaffordable and unreasonable (Douglas 2014). This gap that transmits a false feeling of safety must be dealt at a local level, by reexamining the seismic risk of Seville in an emergency planning context. Not doing this can be considered a situation of weak risk governance by the political institutions of Seville. In order to address disaster risk, not only do the underlying drivers of disaster risk need to be addressed to avoid risk generation, but also the governance of disaster risk must be strengthened in order to be able to do so (UNISDR 2015).

To a wide-ranging extent, earthquake loss studies are founded either on a traditional empirical approach, using macroseismic intensities, or on an analytical approach, by means of physical ground-motion parameters such as spectral accelerations (SA) or using chief variables like the geometry of faults and the wave velocity structure of concerned areas. Nowadays, this can be achieved by means of state-of-the-art techniques like three-dimensional (3D) tomography as proposed by Dong et al. (2020), who adopted $\mathrm{P}$-wave inversion considering active measurements and passive acoustic emission data to detect complex structures.

Consequently, the loss estimation approaches differ in the way the earthquake ground motion is represented, and building vulnerability is treated because the loss estimation results will be provided by the convolution of both terms (expressed in terms of building damage and the matching human losses). According to Molina-Palacios et al. (2019a, b), the first is symbolized as observed vulnerability, while the second characterizes calculated or predicted vulnerability. Both kinds of vulnerability may be denoted by similar means, i.e. damage probability matrices or fragility functions, depending on what type of data is available and which of the basic approaches is to be applied. An elaborate overview of current methodologies for seismic vulnerability assessment is given by Julià and Ferreira (2021) and Hosseinpour et al. (2021); the latter also carries out a comprehensive review of risk assessment made using modern seismic loss estimation software. In a 1D model framework, this work main goal is to investigate the influence of soil amplification on the seismic behaviour of different building typologies with the final target to plot the damage scenarios expected in Seville under a maximum expected earthquake, scrutinizing the need of implementing better local civil protection planning policies, i.e. the creation and employment of local emergency plans and mitigation strategies that presently are not requested for Seville by the Spanish Law.

\section{Area of interest}

Seville, capital of Andalusia, presents a moderate seismic activity. In this region, seismic energy is released predominantly through frequent, small events (Grimison and Chen 1986) and unusually through earthquakes of moderate magnitude whose distribution can be seen in Fig. 1.

According to the seismic hazard map delivered by Martınez Solares et al. (2013), presented in Fig. 2, the region with the highest seismic hazard is the southeastern Andalusia. However, when analysing the history of earthquakes felt in Iberia, the three largest and generally destructive events have been produced by failures that affect the area under study (1504, 1755, and 1969). This event typology frequently has their source in the Atlantic Ocean near the Gulf of Cadiz region. This is a tectonic domain that has experienced a complex Pliocene, distributed over a wide area that explains the recent diffuse seismicity and a non-clear plate-boundary between Africa and Iberia (Benito et al. 2010).

The seismic hazard assessment of moderate seismic areas can be challenging. In fact, the reduced availability of instrumental data of significant seismic series is one of the most important factors due to the lack of strong-motion models covering the magnitude ranges of engineering interest ( $\mathrm{Mw}$ $>$ 5.0; e.g. Benito and Gaspar-Escribano 2007). For Spanish data, the National Geographic Institute of Spain (NGIS) catalogue is an important source of information, where a list 
Fig. 1 Regional tectonics and seismic events (1900-1997) (adapted from Villamor Pérez et al. 2012)

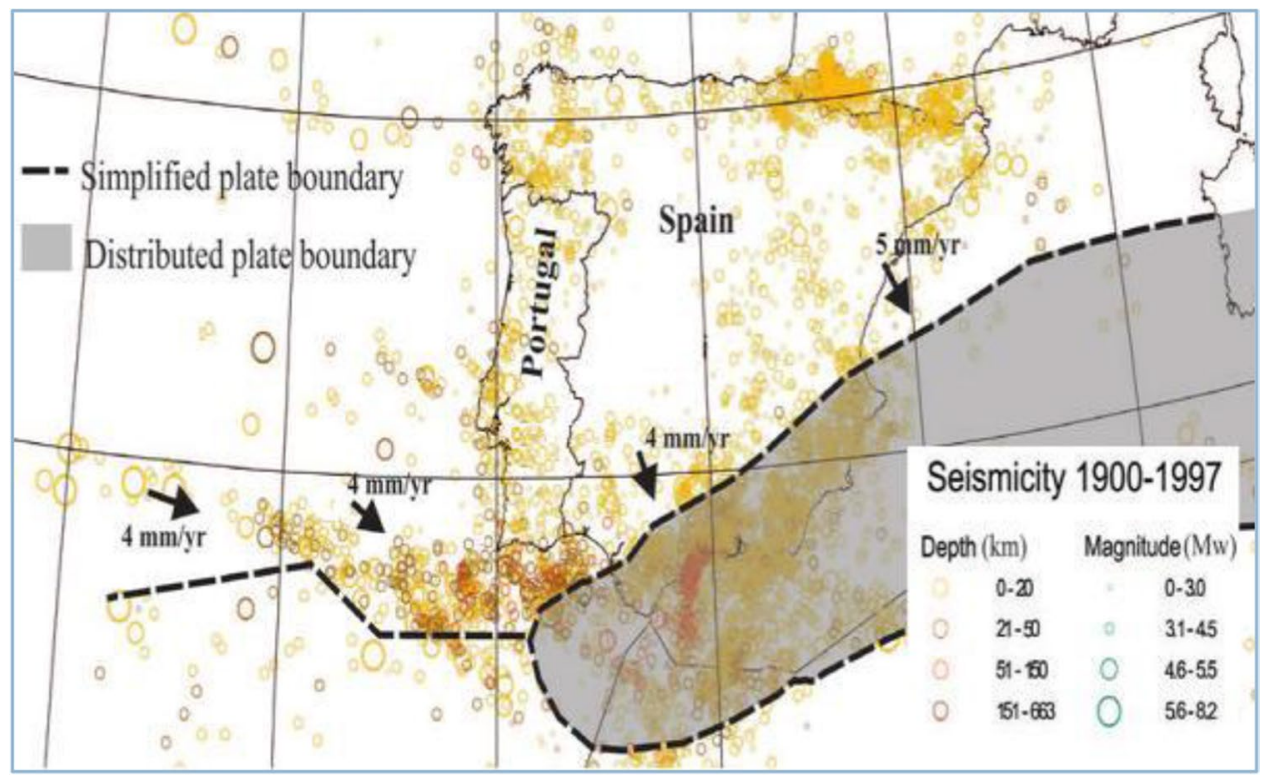

Fig. 2 Spain seismic hazard as EMS intensity for a 475 years return period (IGN-UPM 2013)

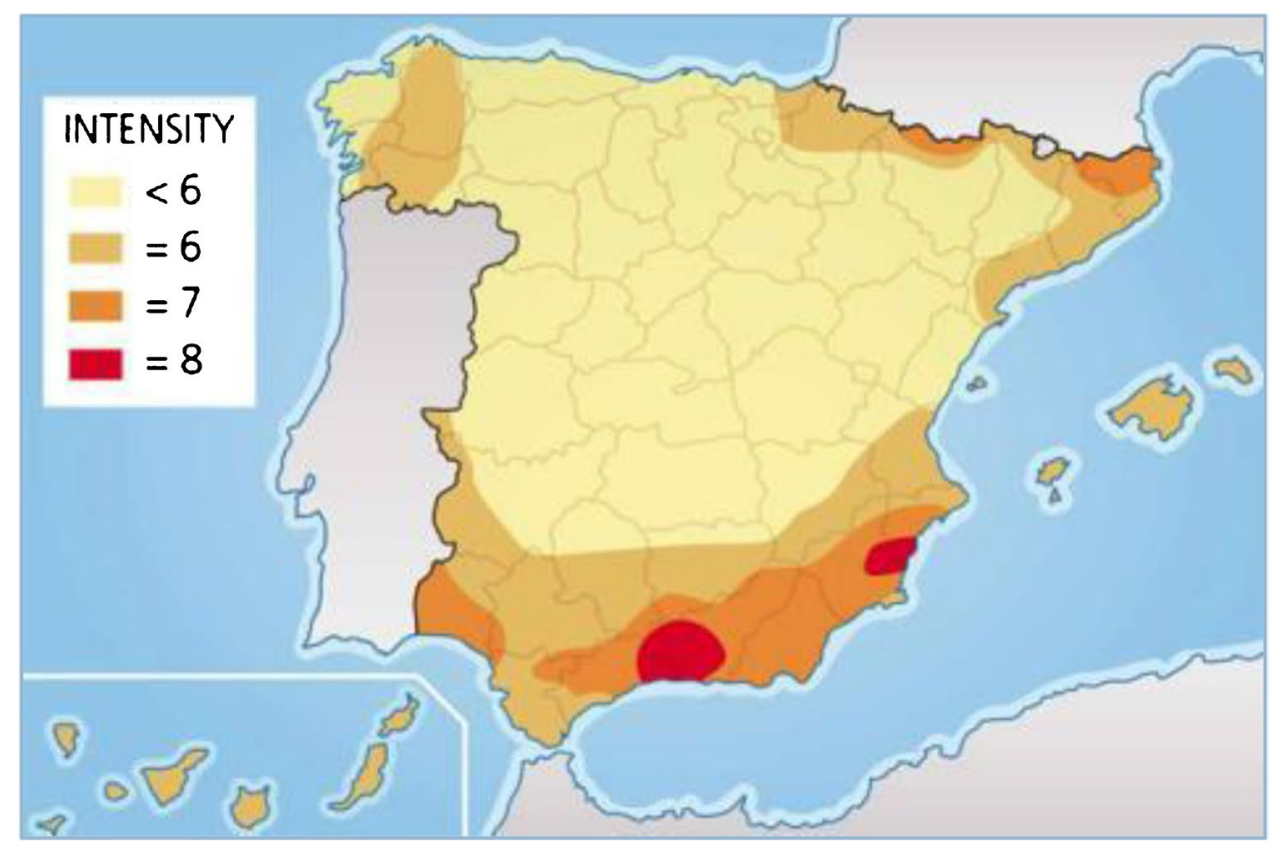

of the major historical events felt in several cities is available. The case for Seville can be observed in Fig. 3.

\section{Seismic hazard assessment}

A main reason for concern arises from the increase of seismic vulnerability of most urban structures especially in developing countries ( $\operatorname{Re} 2000)$. An important factor for the presence of relevant earthquake damage is the level of seismic design and related vulnerability assessment. These variables are analysed against ground motion vibrations like peak ground acceleration (PGA) or peak ground velocity (PGV), among others (Rehman et al. 2016). Seismic hazards can be analysed deterministically (when a particular earthquake scenario is assumed) or probabilistically (in which uncertainties in earthquake size, location, and time of occurrence are explicitly considered (Kramer 1996)). In a deterministic analysis, the controlling fault (i.e. the fault which causes the greatest level of ground shaking) for the building or group of buildings is determined. A maximum credible earthquake (MCE) is then assumed to occur on this fault, and this event is used as the basis of the loss analysis. 
Fig. 3 Historical seismic events felt in Seville in the last millennia (IGN 2020)
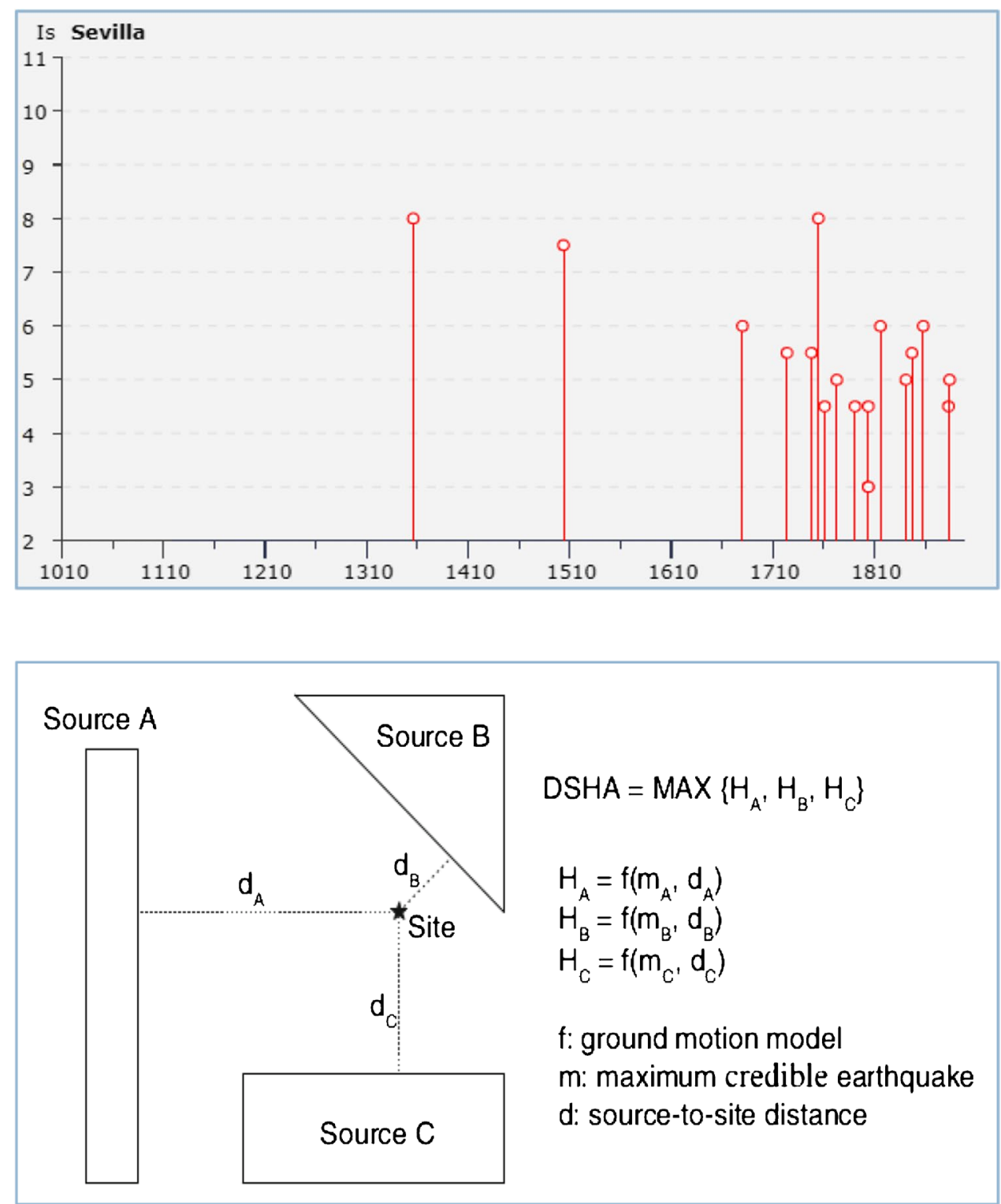

Fig. 4 Schematic diagram illustrating the DSHA (adapted from Wang et al. 2012)
This approach can intuitively be expected to generate a reasonably conservative "worst-case" scenario for loss, especially when combined with a 90 percent confidence level on the loss estimate (Gould 2003). Although the approach offered by a probabilistic assessment is currently the most used by researchers, a deterministic seismic risk analysis (DHSA) is still regarded useful in situations on modelling "worst-case" scenarios (Grasso and Maugeri 2012) (Mostafa and Abdelhafiez 2019). This scenario type is of standard procedure in emergency planning due to a conservative risk estimation approach commonly used by the civil protection systems. Due to this circumstance, the authors have chosen to use DHSA to evaluate the seismic risk of Seville. The calculation procedure, above defined and represented in Fig. 4, can be swiftly described by the following steps (Deif et al. 2013):
1. Delineation of the seismic sources of possible impact on Seville.

2. Assessment of the maximum credible earthquake (MCE) of each seismic source.

3. Select a set of earthquake scenarios (M, R). Scenario means earthquake of specific magnitude (M) at specific distance $(\mathrm{R})$ from the site of interest.

4. Calculate the peak ground motion (PGA) for each scenario. Hazard is defined by the upper limit of the movement at the location.

\section{Delineation of the relevant seismic sources for Seville}

The first step for estimating the earthquake that might occur is to identify areas with different seismic 


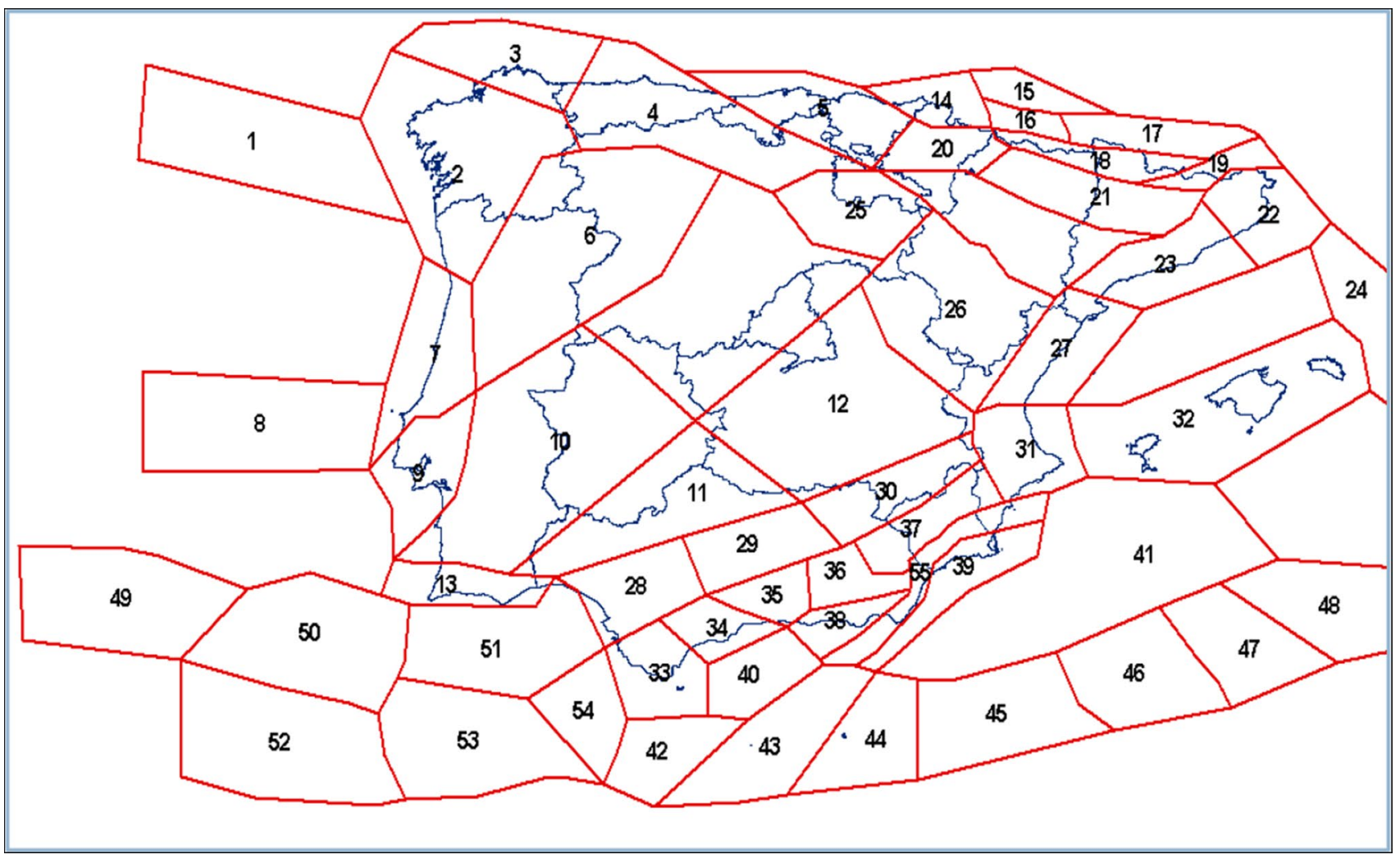

Fig. 5 Seismogenic sources for Iberia (adapted from García-Mayordomo 2015)

characteristics. The set of seismogenic source zones chosen have been the ones considered by the new seismic hazard map of Spain, as proposed by García-Mayordomo (2015). This source set is known as ZECIS or "Commission Model" and is the seismogenic source demarcation (as represented in Fig. 5) that has been used in the update of the official seismic hazard map of Spain carried out in 2012 by the Instituto Geográfico Nacional as the Spanish national authority for seismology.

With the potential source areas defined, the authors resort to the Seismic Catalogue of Spain (IGN-UPM Working Group, 2013) to select the relevant historical seismic events, which affected the city of Seville. For this, the condition employed has been to choose events that were felt in Seville with an intensity scale (EMS98) $\geq \mathrm{V}$. With the application of this criterion, fourteen earthquakes have been selected. They are listed in Table 1.

With the relevant events identified, a search for their seismic source has been conducted. This has been executed by crossing the information of each event epicentre with the ZECIS polygon delimitation. The authors have concluded that of the 59 possible areas only $8(\approx 15 \%)$ have been responsible for the generation of the relevant events, as illustrated in Fig. 6.

\section{Assessment of the maximum credible earthquake for each seismic source}

Following the delineation of the seismic sources, the next step is the definition of the MCE in each of the selected areas. This analysis is made by a seismic evaluation criterion

Table 1 Historical seismic events with potential damage to Seville

\begin{tabular}{llll}
\hline Year & Latitude & Longitude & Mw \\
\hline $\mathbf{1 3 5 6}$ & 36.00 & -10.70 & 7.5 \\
$\mathbf{1 4 3 1}$ & 37.13 & -3.63 & 6.7 \\
$\mathbf{1 4 9 4}$ & 36.73 & -4.41 & 5.7 \\
$\mathbf{1 5 0 4}$ & 37.38 & -5.47 & 6.8 \\
$\mathbf{1 5 1 8}$ & 37.20 & -1.86 & 6.0 \\
$\mathbf{1 5 3 1}$ & 38.98 & -8.93 & 6.5 \\
$\mathbf{1 5 3 1}$ & 37.55 & -2.74 & 6.2 \\
$\mathbf{1 6 8 0}$ & 36.80 & -4.60 & 6.8 \\
$\mathbf{1 7 2 2}$ & 36.40 & -7.77 & 6.5 \\
$\mathbf{1 7 5 5}$ & 36.50 & -10.00 & 8.5 \\
$\mathbf{1 8 5 8}$ & 38.24 & -8.80 & 6.8 \\
$\mathbf{1 8 8 3}$ & 36.85 & -6.92 & 6.0 \\
$\mathbf{1 8 8 4}$ & 37.00 & -3.98 & 6.5 \\
$\mathbf{1 9 6 9}$ & 35.99 & -10.81 & 7.8 \\
\hline
\end{tabular}


Fig. 6 Seismic sources areas of Seville's relevant events (yellow, offshore areas; green, inland areas)
Table 2 Data for Seville's relevant seismogenic sources

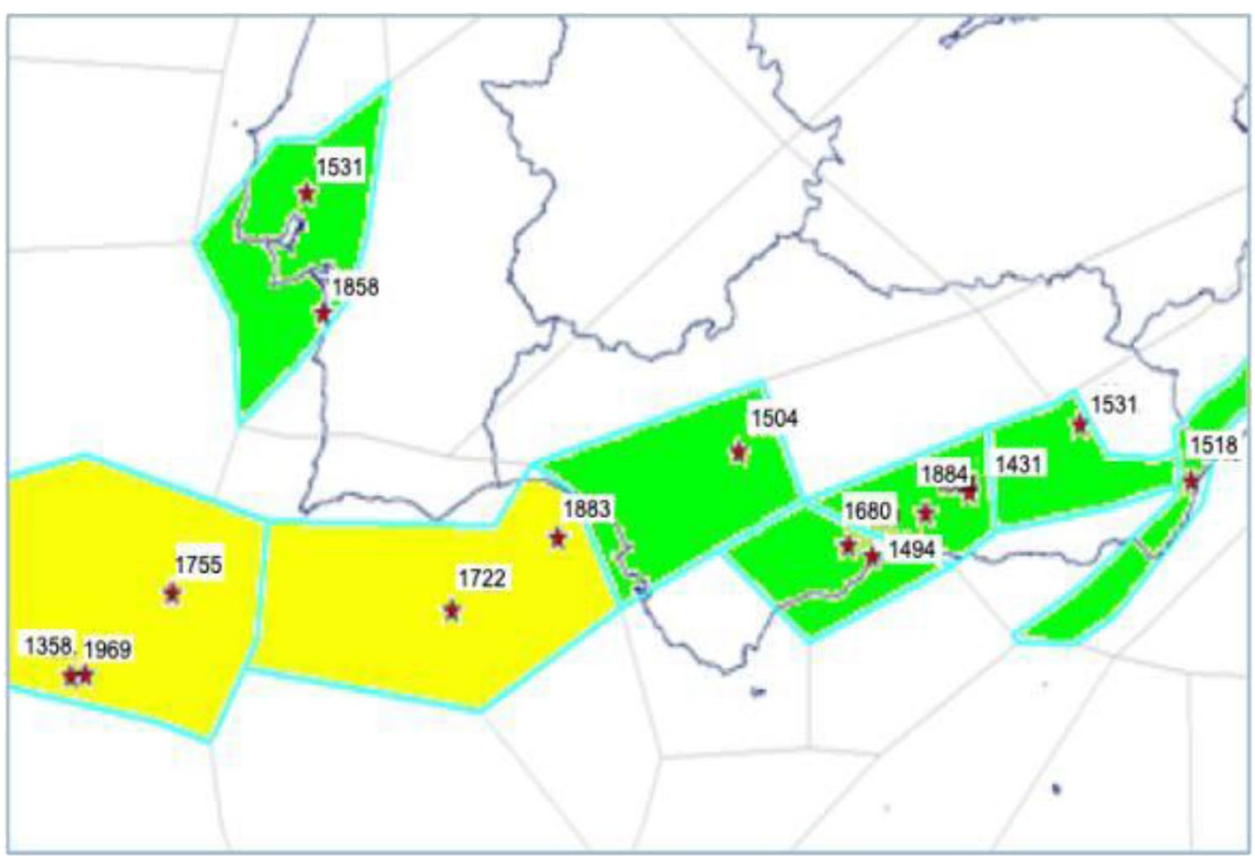

\begin{tabular}{lllllll}
\hline$\#$ & $\begin{array}{l}\text { Source maximum hori- } \\
\text { zontal stress } \mathrm{S}_{\mathrm{Hmax}}\end{array}$ & \multicolumn{3}{l}{ Source seismic parameters } & \multirow{2}{*}{ Source area name } \\
\cline { 3 - 6 } & $\mathrm{b}$ & $\lambda_{(4.0)}$ & $\mathrm{MCE}_{(\mathrm{Mw})}$ & $\mathrm{T}_{\mathrm{MCE} \text { (years) }}$ & \\
\hline 9 & NW-SSE to NNW-SSE & 0.87 & 0.237 & 7.5 & 1125 & Lower Tagus Valley \\
28 & NNW-SSE & 1.10 & 0.186 & 6.9 & 4889 & Western Guadalquivir \\
34 & NNW-SSE & 1.00 & 0.198 & 6.9 & 2071 & Inner Western Béticas \\
35 & NNW-SSE to N-S & 1.12 & 0.576 & 7.1 & 2362 & Granada Basin \\
36 & NNW-SSE & 0.98 & 0.141 & 7.0 & 2561 & S. Nevada GuadixBaza Basin \\
50 & NNW-SSE to N-S & 1.20 & 0.420 & 8.7 & 855 & Gorringe Bank and N.Horseshoe \\
51 & NNW-SSE & $\mathbf{0 . 9 2}$ & $\mathbf{0 . 6 3 4}$ & $\mathbf{7 . 1}$ & $\mathbf{5 8 0}$ & North Gulf of Cadiz \\
55 & NNW-SSE & 1.03 & 0.628 & 7.0 & 965 & Shear area of Eastern Béticas \\
\hline
\end{tabular}

that determines which seismic sources are assigned to the MCE. For this research, the authors have again used the García-Mayordomo's (2015) work. The latter includes a review of all the Spanish historic earthquake data including regional and local studies of events sufficiently significant to induce human or material losses. García-Mayordomo (2015) analysis also enabled the designation of an MCE value for each of the ZECIS areas, which are detailed in Table 2.

In terms of the seismotectonic scheme for the regions considered, the Lower Tagus Valley (LTV) is affected by the NW-SE trending convergence between the Eurasian and African plates. In this tectonic context, some of the related basement faults in LTV are considered active or potentially active under the current stress regime, acting as reverse and strike-slip faults, resulting in moderate to strong intraplate earthquakes (Vilanova and Fonseca 2004). In the Gulf of Cadiz region, the plate boundary resembles a narrow band well demarcated by the seismicity, where large earthquakes
$(\mathrm{M}>7)$ occur in association with horizontal compression $\mathrm{N}-\mathrm{S}$ to NNW-SSE due to the convergence of Eurasia and Africa (Buforn et al. 2004). The intermediate-depth earthquakes, with a distribution in the E-W direction are enclosed by a narrow band less than $20-\mathrm{km}$ wide that broadens to the Straits of Gibraltar. This may also be associated with the convergence process of the Eurasia-Africa plates. In scenarios linked to eastern Andalucía, the plate boundary is more diffuse and covers a wider area that includes the Betics and the Alboran Sea. In this area results of moment rate, slip velocity, and $b$-values show that the strain accumulated in the region is released partially in a continuous seismic activity of moderate magnitude over the entire area (Buforn et al. 2004). Earthquakes with magnitudes larger than 6 occur at prolonged intervals. The stress regime obtained from the focal mechanisms of shallow events is compatible with the horizontal N-S to NW-SE convergence of Eurasia and Africa. However, in the Betics-Alboran area, there is also 
Fig. 7 Hotspots delimitation polygons in each ZECIS (in red)

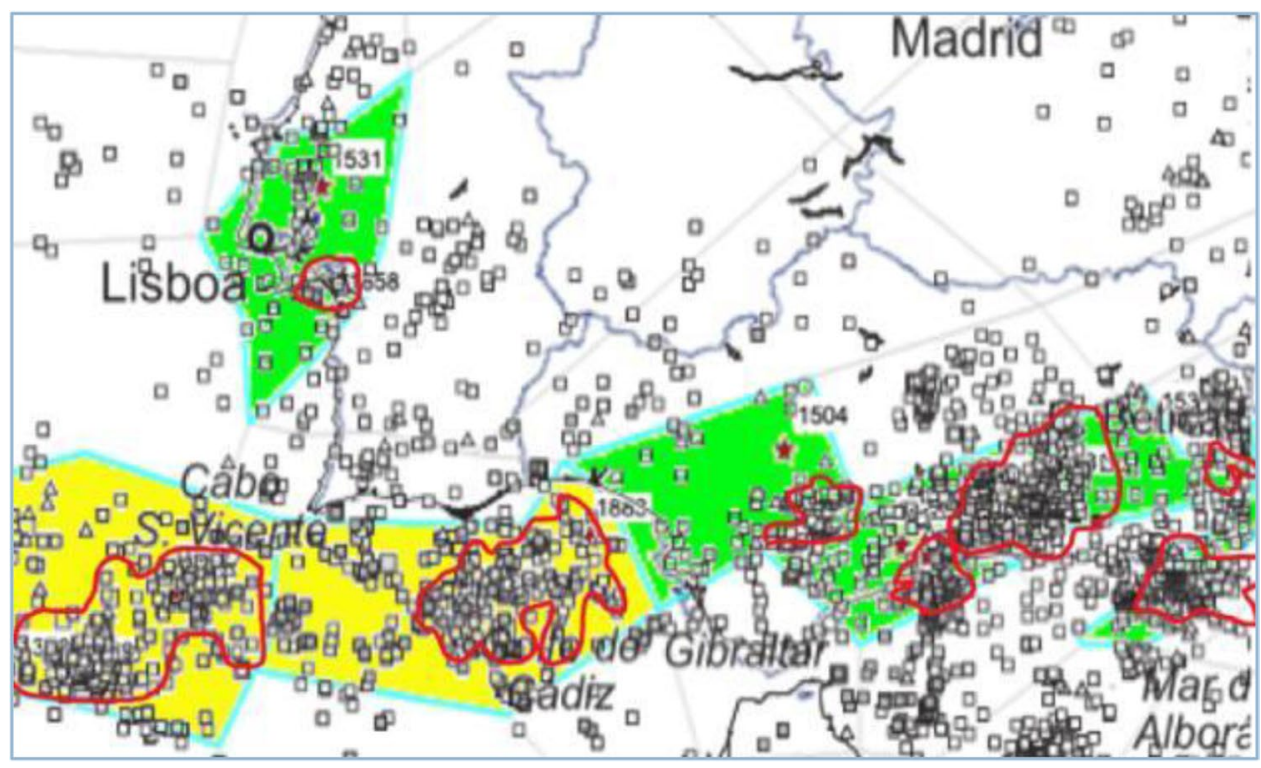

a horizontal extension in an approximately E-W direction (Buforn et al. 2004).

The data related with the location of the seismogenic sources has been estimated by using the "hotspots tool" provided by ArcGis (ESRI 2020). The source material used was the seismic events database provided by the IGN catalogue. This is done by identifying a statistically significant spatial clusters and therefore computing a hotspot polygon (a "cluster" of relevant epicentres) for each ZECIS area as presented in Fig. 7.

For each cluster detected, the centroid coordinates ("probable epicentre" column in Table 2) were extracted, which enabled the calculus of the specific distance $(\mathrm{R})$ from each source to Seville.

\section{Selection of earthquake scenarios with $7 \mathrm{a}$ specific magnitude $(M)$ and distance $(R)$ from Seville}

Using the information acquired, eight scenarios have been established (A to H). For each scenario, a specific epicentre, magnitude, and distance have been defined. Each of them is expressed by (x, y, M, R). The conditions defined for each scenario are described in Table 3.

\section{Determination of bedrock motion (PGA) for each scenario}

For estimating the PGA for each scenario, a model using ground motion prediction equations (GMPEs) has been adopted. GMPEs, or "attenuation" relationships, deliver a mean of calculating the level of ground shaking and its related uncertainty at any given location, based on an earthquake magnitude, a source-to-site distance, a local soil condition, a fault mechanism, etc. Characteristically, the general form of a GMPE is as follows (Stewart et al. 2015):

$\operatorname{Ln}($ amplitude $)=f(M, R)+\varepsilon$

where $M$ represents the moment magnitude, $R$ the source to site distance, and $\varepsilon$ describes the dispersion. The amplitude is the peak ground motion that needs to be estimated by the user (Le Goff et al. 2013).

The function $f(M, R)$ is usually expressed as (Stewart et al. 2015):

$f(M, R)=\alpha+\beta M+\gamma \ln (\boldsymbol{R}+\boldsymbol{g}(\boldsymbol{M}))+\delta \boldsymbol{R}$

where $\alpha, \beta, \gamma$, and $\delta$ are constants.

In a concise approach, the large issue on choosing the model for ground motion in this study area can be resumed by the absence of recent relevant earthquakes in the study region. This problem requires the use of synthetic models for attenuation and seismic studies (Silva et al. 2015). Nevertheless, most of the seismic hazard studies are to be built upon historical data and macroseismic information, which

Table 3 Conditions for each scenario

\begin{tabular}{lllll}
\hline Scenario & $\mathrm{X}$ & $\mathrm{y}$ & $\mathrm{M}(\mathrm{Mw})$ & $\mathrm{R}(\mathrm{km})$ \\
\hline A & -9.04 & 38.66 & 7.5 & 302 \\
B & -5.96 & 37.16 & 6.9 & 26 \\
C & -4.79 & 36.66 & 6.9 & 134 \\
D & -3.99 & 37.08 & 7.1 & 181 \\
E & -2.87 & 37.28 & 7.0 & 277 \\
F & -10.69 & 36.51 & 8.7 & 429 \\
G & $-\mathbf{7 . 9 3}$ & $\mathbf{3 6 . 4 6}$ & $\mathbf{7 . 1}$ & $\mathbf{2 0 1}$ \\
H & -1.57 & 37.40 & 7.0 & 391 \\
\hline
\end{tabular}


Fig. 8 Official distribution of the 606 census tracts in Seville (INE 2012)

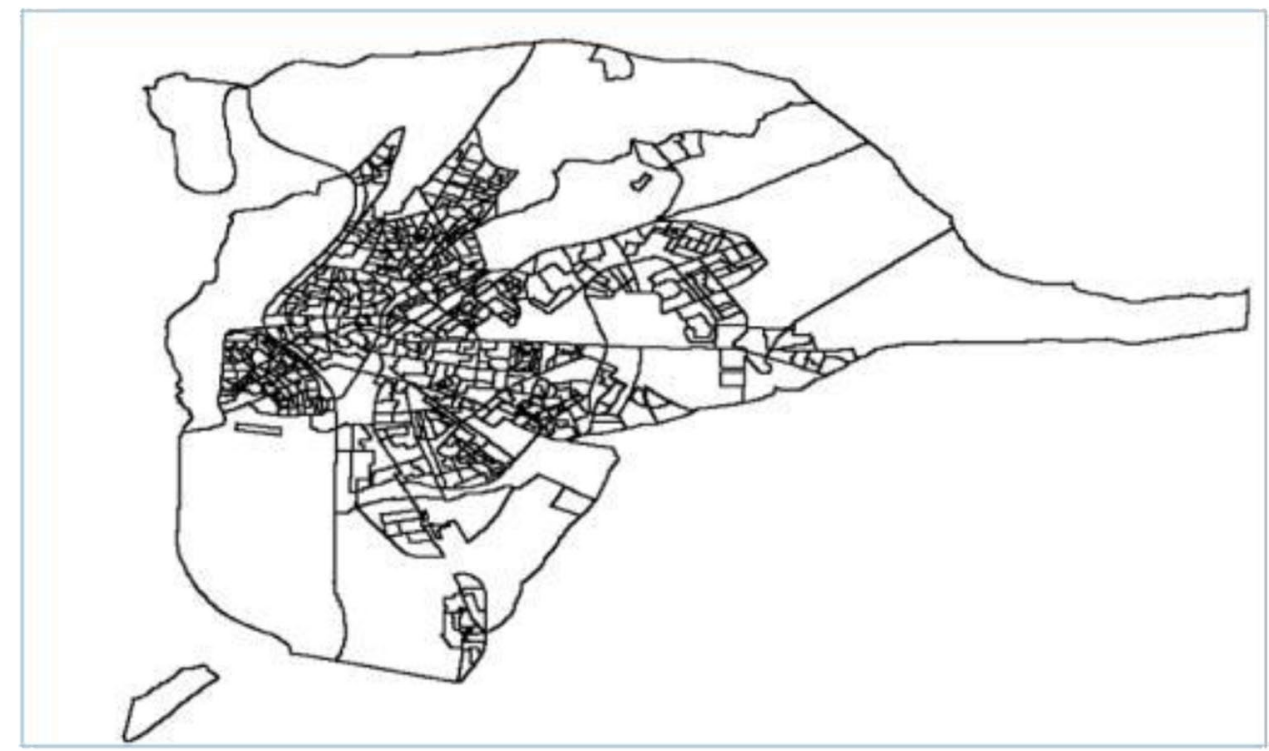

characteristically has a larger uncertainty. This ambiguity can be enhanced due to the complexities of the seismic wave radiation, reflection, and their interaction with potential mining areas; that is, the predictions are accurate for fault slip events, while there can be large errors for non-shear events. This fact enforces the relevant effects of the focal mechanism on ground motion prediction, due to the existence of a correlation between peak accelerations and the ratio of shear wave amplitude computed from the thrust mechanism of the main shock and the strike-slip mechanism of an aftershock (Ma et al. 2019). To overrun these questions, the Vilanova and Fonseca (2007) model has been selected. This model, that has not been yet superseded, is an application that addresses in detail the Western Iberia tectonic characteristics, considering a large spectrum of aleatory uncertainties and takes into attention several previous studies in its creation. Like Silva et al. (2015) and Vilanova and Fonseca (2007), the authors considered mainland Iberia as a stable continental region, and the offshore areas of southwest have been studied as active shallow crustal regions. As such, the seismic characteristics of the eight sources selected have been employed to express the seismicity according to two groups, (i) inland epicentres $(9,28,34,35,36,55)$ and (ii) offshore epicentres $(50,51)$. In this framework - and to minimize the natural inconsistency in working with a low to moderate seismicity area - three GMPEs have been proposed to assess the rock level ground motion:

\section{Events in offshore source areas}

- Atkinson and Boore (1997) $\rightarrow$ Scenarios F and G

$\ln P G A=1.841+0.686(M-6)-0.123(M-6)^{2}-\ln R-0.00311 R$ II. Events in inland source areas

\section{Events with Mw $<5.5$}

- García Blanco (2009) $\rightarrow$ Scenarios below 5.5 are not present

$\ln \boldsymbol{P G A}=-0.2368+1.3285 \boldsymbol{M}-1.0749 \ln \boldsymbol{R}$

Events with $\mathrm{Mw} \geq \mathbf{5 . 5}$

- Mezcua et al. (2008) $\rightarrow$ Scenarios A, B, C, D, E and H

$\ln \boldsymbol{P G A}=0.125+1.286 \boldsymbol{M}-1.133 \ln \boldsymbol{R}$

where $M$ represents the moment magnitude and $R$ the source to site distance

For inland source areas, a partition in function of the event magnitude has been created by the authors due to the lack of instrumental data recorded in Iberia for events with moment magnitude $(\mathrm{Mw})>5.5$. In fact, Mezcua et al. (2008) referred that their ground-motion estimation equation seems only applicable in large distance ranges (distances greater than 50-60 km, corresponding to firm-soil sites in inland events) and for moderate magnitude ( $\mathrm{Mw}>5.5)$. Due to this assumption, for inland events that have a moment magnitude minor to 5.5, the authors have decided to use the ground-motion attenuation relationship of García Blanco (2009).

\section{Selection of the worst-case scenario}

Using the GMPEs described above, the authors have proceeded to analyse each scenario in terms of the resulting ground motion (PGA) for the city of Seville; the census tract has been used as geographic core unit - depicted in Fig. 8 . The census tract represents the smallest territorial unit, for 
Table 4 Census tract scenario statistics for intensities felt at Seville at bedrock level

\begin{tabular}{|c|c|c|c|c|}
\hline Scenario & $\begin{array}{l}\text { PGA- } \\
\text { median }(\% \mathrm{~g})\end{array}$ & $\mathrm{PGA}_{\min }(\% \mathrm{~g})$ & $\mathrm{PGA}_{\max }(\% \mathrm{~g})$ & EMS98 ${ }_{\text {median }}$ \\
\hline A & 2.8 & 2.7 & 2.8 & IV \\
\hline B & 18.5 & 14.9 & 25.7 & VII \\
\hline $\mathrm{C}$ & 4.1 & 3.9 & 4.3 & V \\
\hline $\mathrm{D}$ & 2.9 & 2.9 & 3.1 & IV \\
\hline $\mathrm{E}$ & 1.8 & 1.8 & 1.9 & IV \\
\hline $\mathrm{F}$ & 10.0 & 9.5 & 10.3 & VI \\
\hline $\mathbf{G}$ & 30.6 & 28.5 & 32.1 & VII \\
\hline $\mathrm{H}$ & 1.2 & 1.2 & 1.3 & III \\
\hline
\end{tabular}

which population data are available in several countries, including Spain.

The resulting PGA for each scenario is described in Table 4.

A first statement that can be drawn from the results is that, although the scenario B has the closest epicentre Seville (26 $\mathrm{km})$, it is the event for the scenario $\mathrm{G}(201 \mathrm{~km})$ the one that produces the largest ground motion. This can be explained due to the very low attenuation that is characteristic of the soils of the Gulf of Cadiz and the Low Guadalquivir Basin, as already reported by Casado et al. (2000) and Silva et al. (2015). Additionally, $\mathrm{G}$ is the scenario where the MCE has the lowest return period, that is, 580 years, resulting in an event frequency almost ten times bigger than the one expected for scenario B - that has a return period of 4889 years - leading to an event-related probability much higher for $\mathrm{G}$, thus inducing a larger risk.

\section{Modelling the worst-case scenario}

By using the estimated highest median peak ground acceleration as criterion, also sustained by the associated probability, scenario $G$ was chosen. This step completes the calculation procedure. A seismic event with $\mathrm{Mw}=7.1$ and epicentre at - 7.93; 36.46 - for a WGS84 projection - will be used as base setup for the estimation of the seismic risk for Seville as the worst-case scenario.

\section{Ground motion assessment}

As aforementioned, the data obtained has been computed at the bedrock level, without considering in this instance the site effects phenomena. The results for the PGA along the 606 census tracts units of Seville are very similar. The results have a range of 30 to $32(\mathrm{as} \% \mathrm{~g}$ ), classifying the event as VII in terms of macroseismic intensity using the Atkinson and Kaka (2007) relationship.

\section{Site effects estimation}

Obtaining an accurate soil amplification value is vital to compose safety structural design codes and to reduce the potential risk. With that goal, the average of shear wave velocity in the first $30 \mathrm{~m}$ (Vs30) has been internationally accepted as amplification proxy (Boore 2004). In this context, to determine the possible behaviour of the site effects singularities in Seville's area, an assessment has been made on the local soil geological and geotechnical characteristics. The analytical method for modelling the site response used in this research is based on a 1D soil layer model, by assuming the simplifications referred by Peruzzi et al. (2016). Based on this model, the amplification frequency is dependent on the geometry and the soil properties - density $(\rho)$ and shear wave velocity $\left(V_{\mathrm{s}}\right)$. That is, the site response is the effect of the shallow soil layers on the seismic surface ground motion. In this context, Seville is built on the alluvial floodplain of the Guadalquivir River and several late Pleistocene-Holocene terrace levels (Baena Escudero 1993). The high permeability sediments of the floodplain are constituted of silts and clays that generally evolve to sands and gravels at the bottom Roldán García and Borrero Domínguez, (1988). The divergence in sedimentation, due to variations in the dragging power of the river, has caused a marked asymmetry in the geological constitution of both margins (Ruiz-Constán et al. 2017), as observed in Fig. 9.

In a geotechnical aspect, several regional and local surveys have been carried out in the past. The works by Ruiz-Constán et al. (2017), IGME (1986), and Jaramillo et al. (2005) were significant. But the biggest contribution was offered by the Junta de Andalusia web database ${ }^{1}$. The data stored in this application includes information collected in the context of several geotechnical surveys bored in Seville in the last 50 years including standard penetration test (SPT) and bearing capacity (qA) results with statistical relevance for the first $5 \mathrm{~m}$ layer data, thus providing mechanical characterization of the geological formations of the area. The analysis on the available borehole logs, and related sheets, indicate that the sedimentation layer is thicker in the old city area. In fact, in this location buildings were constructed above a soil that still belongs to the Guadalquivir natural floodplain. The local surveys logs for this area realistically indicate a quaternary deposit that typically have a height of from 3 to $8 \mathrm{~m}$ formed by layers of loose sand and soft medium clay. As we travel further from the river, the data logs show a decreasing height for this alluvium layer, presenting values from 0 (layer not present) to $1 \mathrm{~m}$, coinciding with areas where mainly tertiary soils are present in the top layer (Mazo et al. 2009).

\footnotetext{
1 Accessible in www.juntadeandalucia.es/fomentoyvivienda/ portal-web/web/areas/carreteras/mapa_geotecnico
} 
Fig. 9 Geological map for Seville area (adapted from RuizConstán et al. (2017))

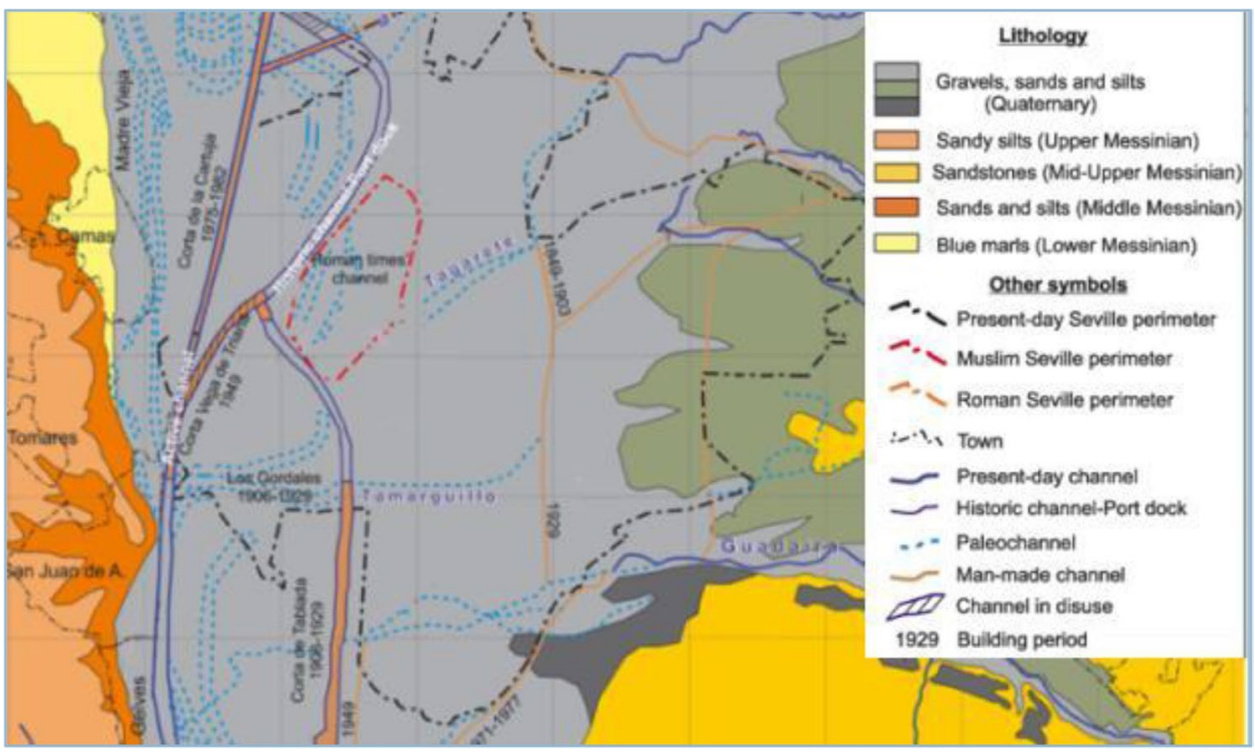

However, the data available for each bore does not have the Vs parameter included. However, a data that exists in virtually each survey is the SPT assessment and/or the qA determination. In fact, despite its shortcomings, it is a usual practice to correlate the SPT number or the qA results with other soil parameters.

So, the authors have used the data available in the records about geotechnical surveys bored in Seville in the last 50 years. The SPT and the qA results have been used to obtain the Vs for the top layer $(\leq 5 \mathrm{~m})$. In this context, the relationships chosen have been:

a) Tezcan and Ozdemir (2011) relationship between qA and Vs for shallow foundation. This is obtained from the following empirical expression, most suitable for $\mathrm{Vs}<$ $600 \mathrm{~m} / \mathrm{s}$

$V s=1.825 \boldsymbol{q A}+77.243$

where $q A$ is in $\mathrm{kPa}$ and $\mathrm{Vs}$ in $\mathrm{m} / \mathrm{s}$.

b) Imai (1981) for the relationship between SPT and Vs. This relation was built with Japanese data, and although — unless better information available — no empirical correlations exist for the area of study, this formula has been adopted in this case. Nevertheless, most SPT-Vs correlations were built by studies investigating quaternary soils and not very consolidated deposits (PérezSantisteban et al. 2016) with characteristics close to Seville's soils, so this incertitude is somewhat mitigated.

$\boldsymbol{V} \boldsymbol{s}=91 \boldsymbol{N}^{0.337}($ All soils $)$

where $N$ is the number of SPT and Vs is the value for shear wave velocity in $\mathrm{m} / \mathrm{s}$
Having establish a relationship between the geotechnical variables (SPT, qA, and Vs), the authors have computed Vs30 discrete values for each of the bored sites. This was completed by using the procedure proposed by Boore et al. 2011 that, for the same soil, relates Vs5 with $\mathrm{Vs} 30$. This has enabled the creation of a general map for Seville's Vs30 by converting the Vs30 discrete data into a continuous one through a kriging interpolation - as proposed by Chilès and Desassis (2018) — in a GIS software environment. The latter geoprocessing input and output are shown in Fig. 10.

In this framework, the soil amplification factor (Ak) has been assumed as the ratio between the elastic design spectra measured in the bedrock (defined in the Eurocode 8 (EC8) as PGA-normalized response spectra) and the one measured in ground surface, affected through a constant soil factor $\mathrm{S}$, which increases uniformly the normalized elastic response spectra in all periods. The amplification factor for ground motion within a site class at a given spectral period has been evaluated from the geometric mean of $5 \%$ damped acceleration response spectra for the horizontal component of shaking and the reference ground motion for the site as proposed by Choi and Stewart (2005). In this context, the ground motion, obtained as PGA values, have been converted into Pseudo Spectral Acceleration (PSA). To do so, the relationship proposed in the Eurocode 8 (EC8) and reaffirmed by (Booth 2007) has been used:

$P G A=\frac{\text { peak 5\%damped PSA }}{2.5}$, for a time period of one second .

In order to calculate the amplification factors, the $A_{k}$ has been inferred from the combination of Joyner and Fumal 
Fig. 10 Local surveys location (left) and related data converted to a continuous Vs30 (m/s) (right)

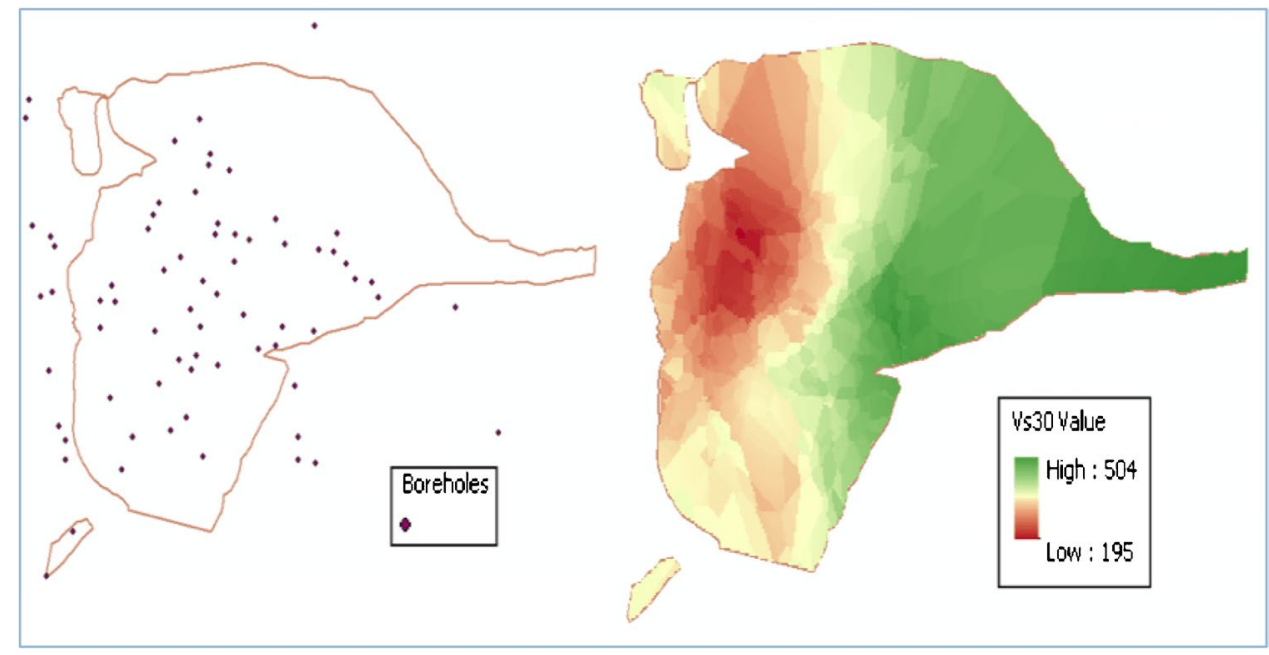

Table 5 Chosen models features

\begin{tabular}{lll}
\hline Model & Data source & $\mathrm{M}_{\mathrm{w}}$ interval \\
\hline Joyner and Fumal 1984 & California & 6.4 \\
Midorikawa 1987 & Japan & 6.7 \\
Borcherdt et al. 1991 & California & 6.9 \\
Stewart et al. 2005 & Worldwide & $4.4-7.4$ \\
\hline
\end{tabular}

(1984), Midorikawa (1987), Borcherdt et al. (1991), and Stewart et al. (2005) models. The value expected value $\left(A_{k}\right)$ for a one-second period has been considered.

$\boldsymbol{A}_{\boldsymbol{k}}=-0.51 \times \log \left(\frac{\boldsymbol{V}_{\mathbf{s} 30}}{\boldsymbol{V}_{\boldsymbol{o}}}\right)$

Joyner and Fumal 1984

where $V_{0}$ is the reference shear velocity.

Midorikawa 1987

$A_{k}=68 \times V_{s 30}^{-0.6}$

$\boldsymbol{A}_{k}=\frac{598}{V_{s 30}}($ strong motion $) ; \boldsymbol{A}_{k}=\frac{701}{V_{s 30}}($ weak motion $)$

Borcherdt et al. 1991

$A_{k}=e^{\left(a_{1}+b_{1} \ln (p H A r)\right)}$

Stewart et al. 2005

where $a_{1}$ and $b_{1}$ are unidimensional parameters and $p H A r$ refers to the reference peak horizontal acceleration.

In fact, the analysis of Table 5 shows that most of the equations chosen use local/regional data that not includes SW Iberia. Therefore, consequent results must be used with caution since the related research scope is not representative for Seville's local conditions. This problem exists due to the

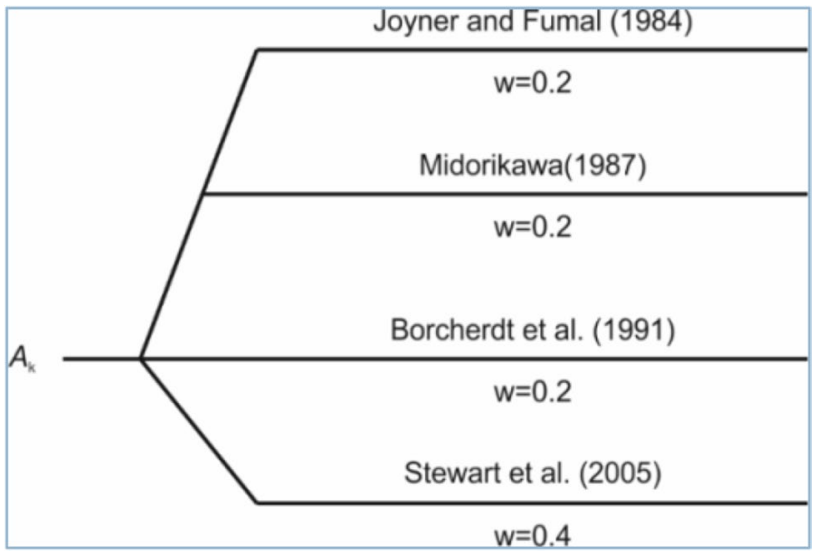

Fig. 11 Logic tree used to estimate empirical amplification factors using a normalized weight (w)

fact that empirical equations for the SW Iberian amplifications are inexistent, in result of the limited observations of major seismic events in this region.

Thus, to account for the potential epistemic uncertainties, amplification factors were estimated using a logic tree approach (Annaka et al. 2007), which combines different methods. Each of the methods - expressed by the Eqs. (8) to (11) - is assigned a weighting factor that is interpreted as the relative likelihood of that method being correct. In this way, the uncertainties of the different methods can be captured in a more effective way. From each source dataset, the normalized weight for each model has been deduced by the authors, as depicted in Fig. 11. A relationship weight of 0.2 was used in the models of Midorikawa (1987), Borcherdt et al. (1991), and Joyner and Fumal (1984) due to the fact that the magnitude interval and the data source locations were somewhat different from the conditions of SW Iberia. The findings of Midorikawa (1987) were derived from data collected from Japanese earthquakes. The data for Borcherdt 
Fig. 12 Seville's building stock age

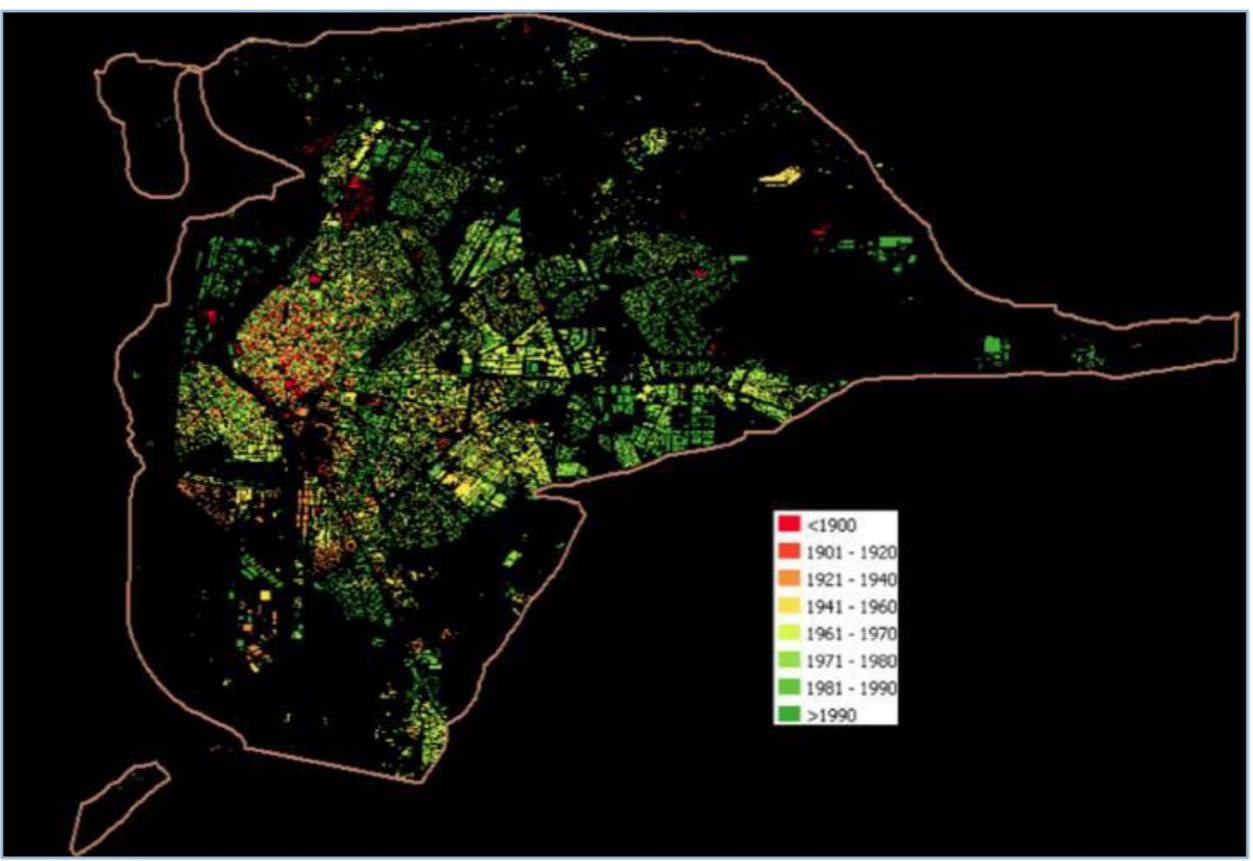

et al. (1991) has its basis in the Loma Prieta event in California and records from nuclear explosions. Joyner and Fumal's (1984) data were essentially collected from the 1979 Imperial Valley event, also in California. Stewart et al. (2005) use a worldwide dataset with a good range in terms of events and related magnitude, thus reducing the sample's data variance. Due to these characteristics, for this last model, a relationship weight of 0.4 was used.

\section{Building vulnerability}

Seville has a varied real estate park where old construction typologies of diverse nature coexist. Among the residential buildings found in the urban centres of Spain, two main classes can be distinguished (Gaspar-Escribano et al. 2008; Quirós 2017):

- Traditional buildings. Usually, the structure of these buildings has been carried out by means of a system of load-bearing walls that support other elements of the building (slabs and the roof structure) and transmit their weight to the foundation, which usually consists of a running shoe. The walls were built with different materials (mud wall, stones, bricks, ashlars, etc.). These buildings are supported by concepts of good constructive practice and form the majority of the traditional construction carried out prior to the 1940 s or 1950 s.

- Technological buildings, carried out with calculation procedures where the efforts on the structure are foreseen and specific solutions are developed for it. These buildings are made up of a system of pillars and beams, which are usually made of reinforced concrete or steel. The implementation of the technological stage occurs over several decades, but it is useful to relate it to the publication of the first Spanish seismic-resistant regulations, which came into force in 1962 with the regulation MV101 (1963).

Given that the real estate park in Seville has buildings of all ages (see Fig. 12), the analysis of this type of structure requires considering all the Spanish seismic-resistant regulations published to date.

\section{Matrix of constructive typologies}

A classification of the Seville's constructive typologies has been made according to the classes established by the Risk-EU project and the publication of the different seismicresistant regulations in Spain (see Table 6). This task was done considering the research made by Salgado-Gálvez et al. (2015) and Benito et al. (2008) specifically, relating Seville's building stock typologies with those of Lorca and Murcia, in general. This assumption is supported by the know similitudes between construction techniques of Lorca (Murcia) and Seville (Andalusia), due to a large socio-cultural relationship between the two regions. In this context, Table 6 summarizes the building typologies considered as representative for Seville, by the authors.

With this classification, and using the methodology proposed by Salgado-Gálvez et al. (2015) in Lorca and Lantada et al. (2010) for Barcelona and Molina-Palacios et al. 
Table 6 Proposed classification for Seville's building stock ( $V_{i}=$ vulnerability index $)$

\begin{tabular}{|c|c|c|c|c|c|}
\hline Typology & Period & Regulations & Risk-UE class & $\mathrm{V}_{\mathrm{i}}$ & $\overline{\text { EMS98 }}$ \\
\hline $\begin{array}{l}\text { Ordinary masonry wall structure and wooden floor } \\
\text { Possible ashlar masonry on the ground floor }\end{array}$ & $<1920$ & Inexistent & M1.1, M1.2, M1.3 & 0.865 & A \\
\hline $\begin{array}{l}\text { Ordinary masonry wall structure and wooden floor } \\
\text { Wall structure of brick and wooden frame }\end{array}$ & $1921-1940$ & Inexistent & $\begin{array}{l}\text { M1.1, M1.2, M1.3 } \\
\text { M3.1 }\end{array}$ & 0.745 & $\mathrm{~B}$ \\
\hline Wall structure of brick and RC frame & $1941-1963$ & Inexistent & M3. 4 & 0.615 & $\mathrm{C}$ \\
\hline Wall structure of brick and $\mathrm{RC}$ frame & $1964-1996$ & MV101/1962 & M3. 4 & 0.615 & $\mathrm{C}$ \\
\hline Structure of RC porticos. & & $\begin{array}{l}\text { PGS-1-1968 } \\
\text { PDS-1-1974 }\end{array}$ & $\mathrm{RC} 1$ & 0.445 & $\mathrm{D}$ \\
\hline $\mathrm{RC}$ structure and frame & 1997-2004 & NCSE-94 & $\mathrm{RC} 1$ & 0.445 & $\mathrm{D}$ \\
\hline Metallic structure & & & $\mathrm{S} 1$ & 0.365 & $\mathrm{E}$ \\
\hline $\mathrm{RC}$ structure and frame & $>2004$ & NCSE-02 & $\mathrm{RC} 1$ & 0.445 & $\mathrm{D}$ \\
\hline Metallic structure & & & S1 & 0.365 & $\mathrm{E}$ \\
\hline
\end{tabular}

Table 7 Vulnerability distribution considered for the buildings in Seville

\begin{tabular}{llllll}
\hline Built & \multicolumn{5}{l}{ EMS98 vulnerability class } \\
\cline { 2 - 6 } & $\% \mathrm{~A}$ & $\% \mathrm{~B}$ & $\% \mathrm{C}$ & $\% \mathrm{D}$ & $\% \mathrm{E}$ \\
\hline Before 1900 & 80 & 20 & 0 & 0 & 0 \\
$1900-1920$ & 75 & 25 & 0 & 0 & 0 \\
$1921-1940$ & 70 & 30 & 0 & 0 & 0 \\
$1941-1950$ & 70 & 25 & 5 & 0 & 0 \\
$1951-1960$ & 45 & 50 & 5 & 0 & 0 \\
$1961-1970$ & 20 & 35 & 45 & 0 & 0 \\
$1971-1980$ & 5 & 40 & 55 & 0 & 0 \\
$1981-1990$ & 0 & 35 & 60 & 5 & 0 \\
$1991-2001$ & 0 & 25 & 65 & 10 & 0 \\
$2002-2011$ & 0 & 15 & 65 & 15 & 5 \\
\hline
\end{tabular}

(2019a, b) for Elche and Alicante, the authors have been able to distribute Seville's building stock with the help of the last Census that was made in 2011 (INE 2012). This distribution has been done according to their structural type and the EMS98 classes of vulnerability from A (more vulnerable) to E (less vulnerable). The results are listed in Table 7.

For each type of construction identified (A to E), a most likely factor of vulnerability has been assigned along with a likely range. Taking into account the works made with the building stock of Lorca (Salgado-Gálvez et al. 2015) and Barcelona (Lantada et al. 2010), an average index of vulnerability $\left(V_{i}\right)$ has been chosen for each typological class identified in Table 6. Then, Eq. 12 has been applied to obtain the $\mu D$ vulnerability value $(1,1.1 \ldots 5)$ and the
Fig. 13 Vulnerability curves for Seville's building stock

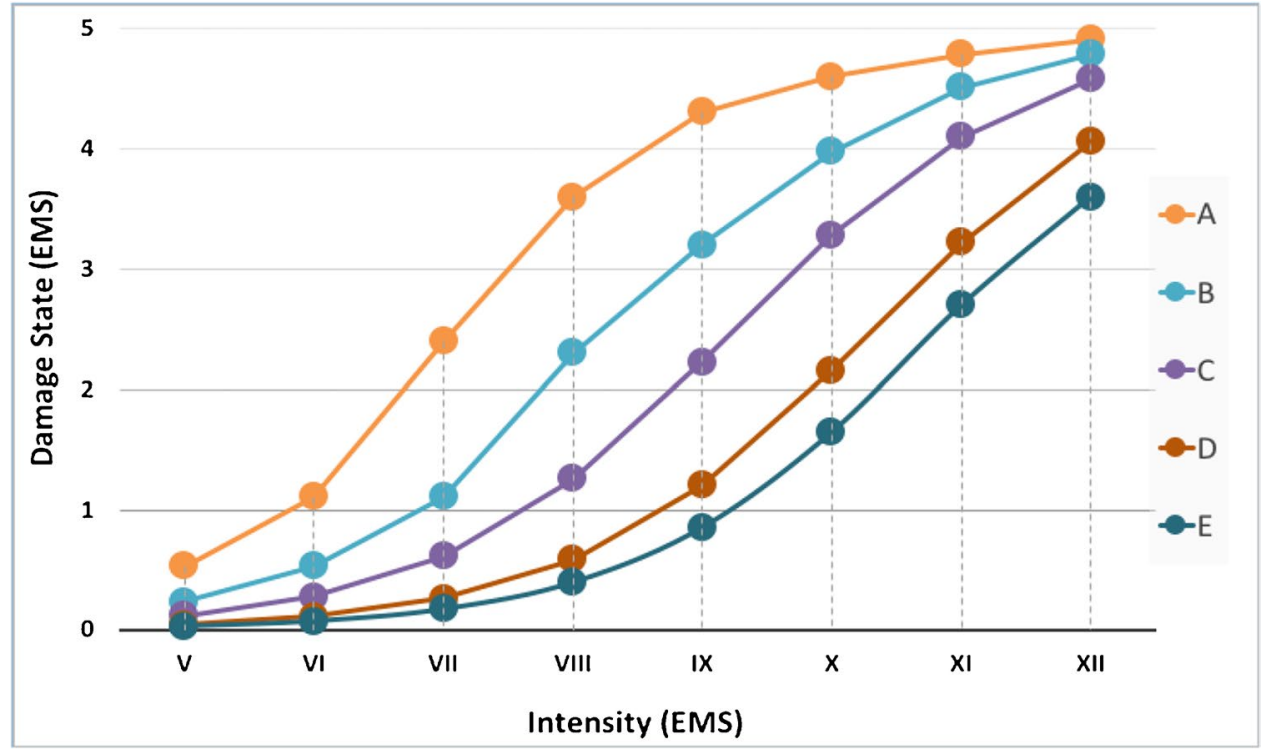


Table 8 Seville's building stock damage state vs. intensities felt

\begin{tabular}{llllll}
\hline & \multicolumn{6}{l}{$\begin{array}{l}\text { EMS98 damage } \\
\text { state }\end{array}$} \\
\cline { 2 - 6 } EMS Intensity & A & B & C & D & E \\
\hline V & 1 & 1 & 1 & 1 & 1 \\
VI & 2 & 1 & 1 & 1 & 1 \\
VII & 3 & 2 & 1 & 1 & 1 \\
VIII & 4 & 3 & 2 & 1 & 1 \\
IX & 5 & 4 & 3 & 2 & 1 \\
X & 5 & 4 & 4 & 3 & 2 \\
XI & 5 & 5 & 5 & 4 & 3 \\
XII & 5 & 5 & 5 & 4 & 4 \\
\hline
\end{tabular}

related vulnerability curves (Fig. 13) as described by Giovinazzi and Lagomarsino (2004):

$\boldsymbol{\mu} D=2.5\left[1+\tanh \left(\frac{1+6.25 V i-13.1}{2.3}\right)\right]$

where Vi represents the average value of vulnerability of each building

These curves have been created using the damage probability functions based on the macroseismic scale EMS98 (Grüthal 1998) and with the support of a composed exposure database for the buildings of Seville. The information used to assembly the database for this study is based on the Dirección General del Catastro, (available at http://www. sedecatastro.gob.es).

Depending on the macroseismic intensity (I-XII), the vulnerability curves indicate the likelihood of a building typology to suffer some degree of EMS98 (Grünthal 1998) damage state (D1 to D5) when facing an earthquake (Lantada et al. 2010). The results for Seville's building stock are shown in Table 8.

\section{Human losses}

This research used Coburn et al. (1992) procedure to estimate the human morbidity and lethality. Victims are accounted on the basis of the number of collapsed buildings and their lethality factor. With this method, the occupants trapped by the debris are calculated as a percentage of the total population that lived in that building. This method allows the estimation of the following loss variables:

- Victims with minor injuries

- Victims with hospital needs (major injuries)

- Deaths

\section{Seismic risk and results}

Seismic risk $(S R)$ is defined by Kunreuther (1996) as the degree of loss (vulnerability) of a particular event, $i$, and the likelihood of $\mathrm{Hi}$ :

(SR) $i=V \times H i$

where $V$ is value of vulnerability and Hi the hazard likelihood

In this research, the final value of risk is achieved by a combination of hazard (the earthquake intensity) on each building site and the macroseismic vulnerability of each dwelling typology via the EMS98 (Grünthal 1998). The significance of risk (as total loss) for each scenario is expressed in terms of:

- Victims with minor injuries

- People displaced

- Buildings with slight damage

- Buildings with moderate damage

- Buildings with severe damage

- Collapsed buildings

\section{Scenario G event: results}

For the scenario $\mathrm{G}$, the results of the modelling were:

a) Isoseismal representation

Due to the low attenuation that exists between the Gulf of Cadiz and Seville (Casado et al. (2000a, b), the values for intensities through Andalusia are to be considered relevant, even not taken in account the site effects phenomena. This idea is expressed in Fig. 14, where a simplified isoseismal map represents the intensities shape $(\mathrm{EMS}>\mathrm{V})$ distribution at bedrock level.

Seville is located in the orange area with intensities VII-VIII EMS. This intensity range predicts possible moderate to heavy damage in a considerable number of buildings and the probable presence of victims in the affected areas. For a more detailed level, an isoseismal map of Seville is presented in Fig. 15.

The existence of site effects is well represented in Fig. 15, where the alluvial region near the Guadalquivir - that has the lowest Vs30 values — is more affected by amplifications, raising the felt intensity to VIII.

b) Building losses

Due to this scenario, Seville will face VII to VIII EMS intensities. As stated before, this assumption predicts the 
Fig. 14 Simplified regional isoseismal map for scenario $\mathrm{G}$

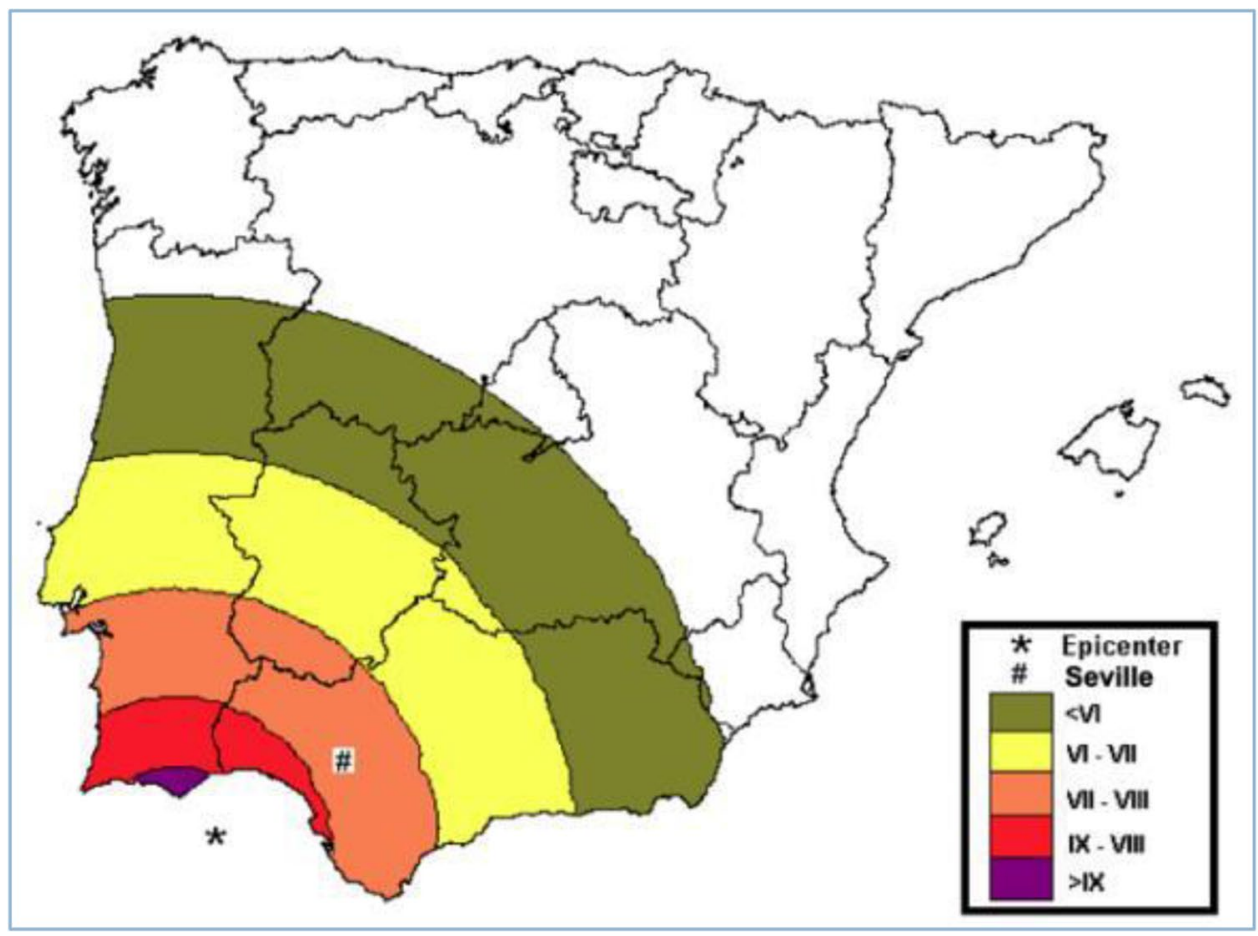

Fig. 15 Scenario G output results for site effects influence (left) and EMS Intensities (right)

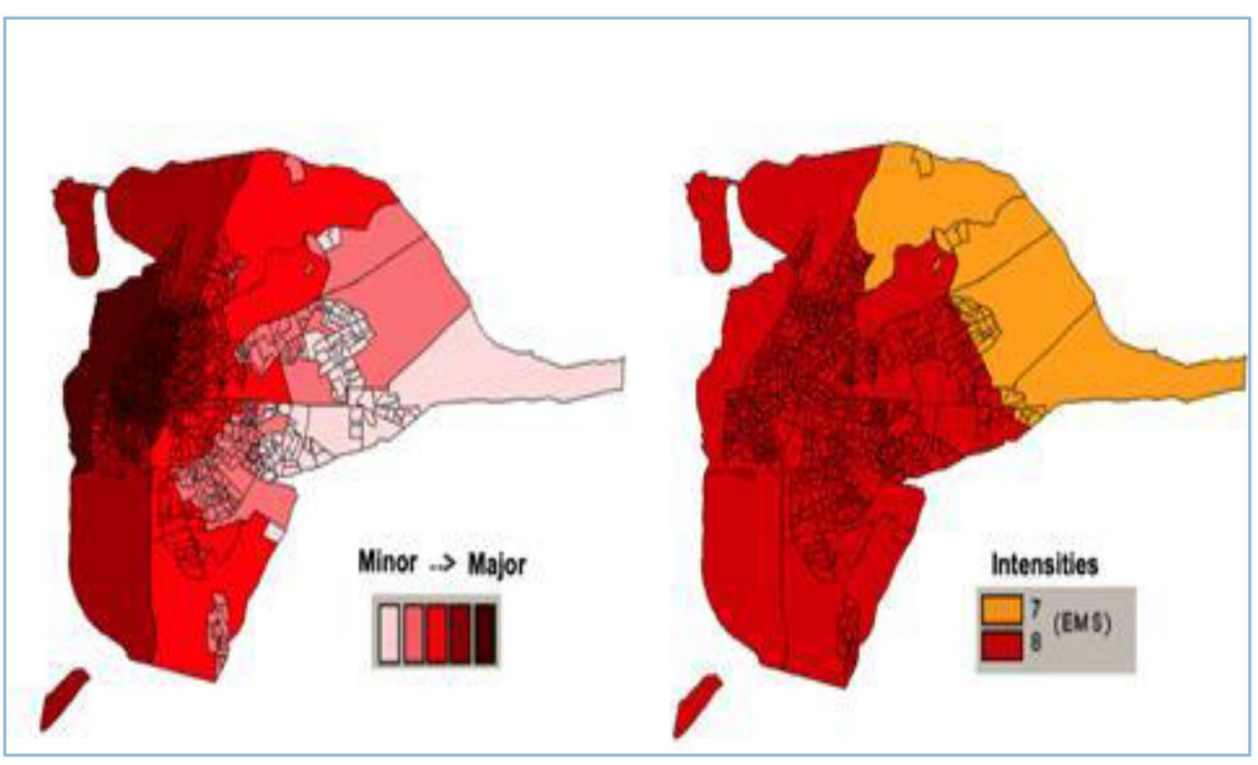

Table 9 Probable building damage and related homeless residents

\begin{tabular}{llll}
\hline & D3 & D4 + D5 & HOMELESS \\
\hline Building losses & 27032 & 26459 & 71634 \\
\hline
\end{tabular}

existence of moderate to heavy damage in a considerable number of buildings. This is described in Table 9, where a probable number of displaced persons is also reported.

D3, moderate damage; D4, precollapse; D5, collapse
Table 10 Output results for scenario G

\begin{tabular}{llll}
\hline & S1 & S2 + S3 & S4 \\
\hline $\begin{array}{l}\text { Human losses } \\
\text { AFF }\end{array}$ & 20989 & 22311 & 5472 \\
\hline
\end{tabular}

a) Human losses

In terms of aggregated results for human losses, Table 10 has been built. It's expected the presence of deaths due to 
Fig. 16 Local authority's requirement in seismic emergency planning - actual (left) and proposed (right)

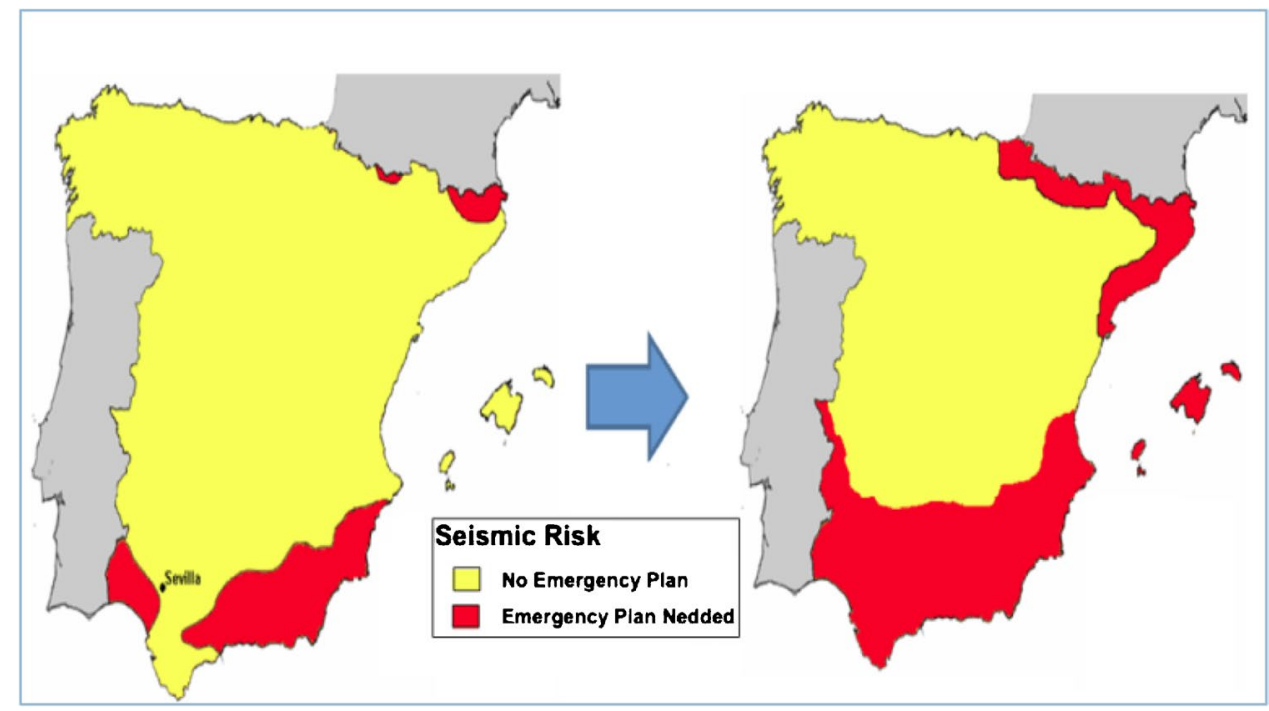

the severe damage in older buildings where precollapses are expected.

$\mathrm{S} 1$, slightly wounded; S2, injuries requiring hospitalization; S3, serious injuries requiring immediate medical treatment; $\mathrm{S} 4$, dead or stranded beyond effective rescue

\section{Local emergency planning}

The result of this research demonstrates the presence of a risk that must be dealt with organized actions sustained in emergency preparedness. Hence, although the event itself cannot be predicted, the related consequences can be mitigated by strengthening the preparedness level, thus increasing the community's resilience.

The results also allow establishing a relative assessment of the risk in the different areas and identifying those that, due to their higher risk index, require detailed studies. In this framework, the basic directive of civil protection planning against seismic risk (Directriz básica de planificación de protección civil ante el riesgo sísmico, DBPPCRS 1995, updated in 2004) was established in 1995. This is the Spanish norm defining the conditions under which emergency response plans for earthquakes must be carried out. Three execution levels exist: general, regional and local. The general level is represented by the seismic hazard map of Spain depicted in DBPPCRS (2004), which gives the expected MSK intensities for the 500-year return period used as reference for most preliminary evaluations. Areas displaying high hazard (IMSK $\geq$ VII, Fig. 16) must elaborate special regional plans for seismic risk. In terms of emergency planning, this concept is rendered in those areas where earthquakes of intensity EMS degree $\geq$ VII are foreseeable. However, Seville accordingly to this criterion is not required to have such emergency plan, as observed in Fig. 16 (left). It
Table 11 Probabilities for intensities to be felt in Seville in a time frame (Govantes 1984)

\begin{tabular}{llllll}
\hline & & & \multicolumn{3}{l}{ Probability of occurrence $(\%)$} \\
\cline { 5 - 6 } \begin{tabular}{lllll} 
Intensity \\
\cline { 5 - 6 } MSK)
\end{tabular} & $\begin{array}{l}\text { Return } \\
\text { period }\end{array}$ & & In 50 years & In 200 years & In 500 years \\
\hline VIII & 225 & & 19.96 & 56.96 & 89.22 \\
$\geq$ VII & $\mathbf{5 0}$ & & $\mathbf{2 8 . 4 3}$ & $\mathbf{7 3 . 7 6}$ & $\mathbf{9 6 . 4 3}$ \\
$\geq$ VI & 27 & & 84.84 & 99.94 & 99.99 \\
$\geq$ V & 10 & & 99.48 & 100.00 & 100.00 \\
$\geq$ IV & 6 & & 99.98 & 100.00 & 100.00 \\
\hline
\end{tabular}

should be noted that in the surrounding area, the seismic acceleration of an event can reach $0.08 \mathrm{~g}$, without asserting possible cumulative site effects.

The authors admit their puzzlement on how a small municipality like, for example, Benacazón, is required to have a local emergency plan for seismic risk, and Seville - only located $20 \mathrm{~km}$ to the East — can be excluded from this obligation. Furthermore, is the fact that this decision, virtually recalling a "Ratcliff Line" scenario $^{2}$, is based in a probabilistic setup where a degree of incertitude is naturally assumed. Nevertheless, as observed in this research, Seville can have events that produce IMSK $\geq$ VII. This class of event has a probable estimated return period of 50 years, as presented in Table 11.

The DBPPCRS delivers a reference frame for establishing seismic risk emergency plans. A problem arises when

\footnotetext{
2 The Radcliffe Line was the 1947 boundary demarcation between India and Pakistan. Named after Cyril Radcliffe, who received the impossible responsibility to equitably partition the Punjab and Bengal provinces of British India.
} 
the probabilistic approach of the NSCE is advocated to create the DBPPCRS. The former deals with planning building structures and the latter with civil protection procedures. They have not the same goal and a PSHA does not cover a worst-case scenario, which is paramount in terms of civil protection scenarios. This unbalanced situation is verifiable in Seville's case, due to the fact that in this research it is concluded that locally a seismic event can be felt with IMSK between VII and VIII, which are intensity values that will cause human losses.

Apart from the obvious inconsistency, some negative consequences are foreseen, like the amount and availability of response resources could be inadequately distributed, making the entire response system results unbalanced. Another consequence is related to the doubts about the reliability of the earthquake risk results that may arise to end-users. If the results appear unjustifiably dissimilar, they may be rendered useless and eliminated from public awareness. This is just the scenario that risk mitigation planners want to avoid and fought (Gaspar-Escribano and Benito 2008).

In conclusion, the DBPPCRS should not be associated with the NSCE. The former should follow a deterministic approach, and not mimic the probabilistic approach of the latter. To minimize this problem, the authors recommend the following:

a) The revision of the local seismic emergency planning criterion expressed in the DBPPCRS. Areas displaying a probable event intensity IMSK $=$ VI for a 500 return period should be included, assuming a general mandatory criterion for emergency planning of IMSK $\geq \mathrm{VI}$, as represent in red colour in Fig. 16 (right).

b) Seville's City Council, not being legally obliged to make a specific emergency plan for seismic risk ("Plan de Actuación Municipal"), can choose to do so within its administrative autonomy ${ }^{3}$. Due to the existent risk, this would be a service that elected representatives would do for their city and the inhabitants they represent.

Lastly, it is interesting to realize that the proposed increase of the red area in Fig. 16 - the area with larger hazard approximates the latter with the seismic regions classification that existed in older Spanish seismic building Norms. In fact, norms PGS-1 (1968) and the PDS-1(1974) based their maps according to a hazard expressed in values of maximum intensity expected, accompanying a deterministic approach. The city of Seville was classified by both overruled norms as VI $<$ MSK $<$ VII in terms of maximum intensity, a value nearer to the one obtained in this work.

\footnotetext{
3 The current local emergency plan ("Plan territorial de emergencia municipal") was approved in 2015 and consists in $7 a$ general approach to local risks, not dealing with the specifically of the seismic risk.
}

\section{Model limitations and shortcomings}

The main aim of the study was to assess the influence of soil amplification on the seismic behaviour of different building typologies with the end target of plotting the damage scenarios expected in Seville from a maximum expected earthquake. Although the study conducted a detailed survey, there were certain limitations while exploring the aim of the study. The authors believe that that the usage of information that is uncertain is possible as long as any decisions and actions based upon the information are made with a full understanding of the associated uncertainty and its implications. However, a systematic study of the uncertainties in this procedure has yet to be carried out and will be a key aspect of future improvements. It is expected that the enhanced points below will help future researchers to avoid facing the same shortcomings:

- The method proposed is one-dimensional and observed as an approximation. It is intended to supply a rapid estimate of deaths from ground shaking to within about a factor of 3 or 4 in the majority of situations, using only cadastre information about the quality of the building stock affected and the census data for the resident population.

- Deaths and injuries from collateral hazards such as landslides or fires are not included.

- Field observations and modelling indicate that the elastic interaction between active faults can lead to variations in earthquake recurrence intervals and associated intensities. As such, the ground shaking estimation is subjected to the limitations of the attenuation laws selected with additional errors from the assignment of a single intensity value to a census track area;

- Assuming that the building stock can be classified in only 5 classes introduces further uncertainty.

- The research area is characterized by a lack of instrumental data for larger events, meaning larger uncertainty.

- Due to the lack of information on propagation speeds at the level of each local geological survey, it was decided to use the SPT parameter, which is a Vs30 proxy. However, Vs30 is also per se a proxy for amplifications. This procedure, that is also proposed in EC8, tends to increase the related uncertainty.

- Seismic vibration measurements should be done in the future to determine the proper vibration periods for each type of terrain.

- An analysis on the frequency content of MCE and on the building's height regarding vulnerability assessment is advised in future research.

- A numerical modelling to validate the options taken and the results obtained should be considered. 


\section{Conclusions}

The seismicity of Seville is moderate but major events with return periods larger than 200 years have historically occurred. This regional characteristic exceeds the life of various generations producing an uninformed population when dealing with the seismic hazard. On the other hand, the Spanish civil protection system must be properly prepared to deal with a major seismic event and the potential losses associated. For that goal, planning scenarios must be evaluated regarding the hazard itself as well as with the structural vulnerability of present dwellings. The hazard component was build using a DHSA approach, still regarded useful in situations on modelling "worst-case" scenarios commonly used by the civil protection systems. In that scope, the maximum credible earthquake for Seville has been investigated. The ground-motion attenuation relationship chosen for this research were Atkinson and Boore (1997) for offshore events and García Blanco (2009) for inland epicentres with $\mathrm{Mw}<5.5$ or Mezcua et al. (2008) for events with $\mathrm{Mw}>5.5$. The analysis determined that the MCE for Seville is an event with $\mathrm{Mw}=7.1$ and epicentre in the Cadiz Gulf, adjacent to the Guadalquivir bank. The expected intensities felt in Seville have also been estimated considering potential site effects due to the geological bed formations that exist below Seville. A classification of the constructive typologies of Seville has been made according to the classes established by the Risk-EU project and the years of entry into force of the different seismic resistant regulations in Spain. With this typology classification, and using the methodology proposed by Salgado-Gálvez et al. (2015) (for Lorca) and Lantada et al. (2010) (for Barcelona), the authors have been able to distribute Seville's building stock according to their structural type and the EMS98 classes of vulnerability from A (more vulnerable) to $\mathrm{E}$ (less vulnerable). This has led creating the respective fragility curves. Finally, the authors have selected the procedure of Coburn et al. (1992) to estimate the human morbidity and lethality.

The results demonstrate that an MCE event can produce in Seville EMS98 intensities of VII and VIII, leading up to 5500 deaths, more than 20000 injured people requiring medical attention and about 70000 homeless. This data is a direct result of the building damage associated with this major event, which can induce the ruin of up to 25 000 buildings. The aforementioned damage effects have clearly demonstrated the presence of a risk that must be dealt with organized actions like operational preparedness and emergency planning.

The basic directive of civil protection planning against seismic risk (DBPPCRS) is the Spanish norm that sets up the general conditions under which emergency response plans for earthquake disasters must be carried out. However, the DBPPCRS is based on a probabilistic hazard analysis, which was accomplished during the elaboration of the Spanish "Norma de Construcción Sismorresistente" (NSCE). Furthermore, the detail of the hazard analysis made by the NSCE is low and does not consider the presence of potential local amplifications. In fact, the DBPPCRS dispenses, for emergency planning, areas with a probable intensity MSK = VI for a 500 return period, and by inherence the need to consider the presence of site effects in this areas. This unbalanced situation results in the existence of an ambiguous outcome in terms of border line criterion for the necessity of local seismic emergency plans - municipalities where predict intensities are larger than MSK VI. This is the case of Seville where a seismic event can produce IMSK VII-VIII, generating human losses.

In conclusion, the DBPPCRS should follow a deterministic approach as recommend by the emergency planning best practices. It should avoid using the probabilistic approach of the NSCE-02, which was created considering structural engineering standards and goals. This uncomfortable situation can be explained by the existent "urban myth" that building codes, like the NSCE-02, are made to save buildings. But they are not, as they are made to saves lives. This is a misconception that exists among the population and even today among emergency planners. So, if the NSCE-02 is made to save lives, the post event usability of the buildings is disregarded. In fact, if building codes were to consider a post event usage factor, the level of project safety and physical construction cost would become socially intolerable.

As a final remark, the authors are bound to conclude that the citizens of Seville are not being prepared with the necessary tools to deal with seismic risk. To correct this liability, a revision of the local seismic emergency planning criterion expressed in the DBPPCRS must be endorsed by the Spanish Administration, by including regions of Spain where is probable the occurrence of an event with intensity IMSK $=$ VI for a 500 return period. This criterion should be altered by also considering the presence of potential amplifications. For now, and considering the extended time frame associated with the change of national codes, only a police decision made by the Seville City Council could correct the status quo. In fact, as local civil protection authority, the City Council is not legally obliged to make a local emergency plan for seismic risk, but considering the expected losses that are caused by the simulated scenario, that is a natural decision which any local decision maker should take. In fact, this state of affairs is a conundrum that in the near future only an audacious local policy change can answer. Making that option by the path of a "Plan de Actuación Municipal", as foreseen by Spanish Law, is paramount. 
Acknowledgements The authors would like to express their gratitude to the two anonymous reviewers whose suggestions helped improve and clarify this manuscript.

Funding Open Access funding provided thanks to the CRUE-CSIC agreement with Springer Nature.

Availability of data and materials The data and material used in this research are partly available in the body of the article; other data/material are also available to public and will be provided through writing to the authors.

\section{Declarations}

Conflict of interest The authors declare no competing interests.

Open Access This article is licensed under a Creative Commons Attribution 4.0 International License, which permits use, sharing, adaptation, distribution and reproduction in any medium or format, as long as you give appropriate credit to the original author(s) and the source, provide a link to the Creative Commons licence, and indicate if changes were made. The images or other third party material in this article are included in the article's Creative Commons licence, unless indicated otherwise in a credit line to the material. If material is not included in the article's Creative Commons licence and your intended use is not permitted by statutory regulation or exceeds the permitted use, you will need to obtain permission directly from the copyright holder. To view a copy of this licence, visit http://creativecommons.org/licenses/by/4.0/.

\section{References}

Akkar S, Bommer J (2010) Empirical equations for the prediction of PGA, PGV, and spectral accelerations in Europe, the Mediterranean region, and the Middle East. Seismol Res Lett 81(2):195-206

Alimohammadi H, Dastjerdi KY, Yaghin ML (2020) The study of progressive collapse in dual systems. Civil Environ Eng 16(1):79-85. https://doi.org/10.2478/cee-2020-0009

Annaka, T., Satake, K., Sakakiyama, T., Yanagisawa K, Shuto N (2007) Logic-tree approach for probabilistic tsunami hazard analysis and its applications to the Japanese coasts. Tsunami its hazard Indian Pacific Ocean. 577-592

Atkinson GM (2008) Ground-motion prediction equations for eastern North America from a referenced empirical approach: implications for epistemic uncertainty. Bull Seismol Soc Am 98(3):1304-1318

Atkinson GM, Boore DM (1997) Some comparisons between recent ground-motion relations. Seismol Res Lett 68(1):24-40

Atkinson GM, Kaka SI (2007) Relationships between felt intensity and instrumental ground motion in the central United States and California. Bull Seismol Soc Am 97(2):497-510

Baena Escudero R (1993) Evolución cuaternaria (3M. a de la Depresión del mediobajo Guadalquivir y sus márgenes (Córdoba y Sevilla). Geomorfología, Aluvionamientos, Formaciones superficiales y Secuencia paleolítica (In Spanish)

Benito B, Gaspar-Escribano JM (2007) Ground motion characterization and seismic hazard assessment in Spain: context, problems and recent developments. J Seismol 11(4):433-452

Benito B, Gaspar-Escribano JM, Martínez-Díaz J, García Rodríguez MJ, Jiménez Pena ME, Canora C, Álvarez Gómez JA (2008) An approach for identification of areas with higher expected damage and definition of priority levels for prevention plans in Murcia Province (SE Spain). Bolletino di Geofisica Teorica e Applicata 49(1):3-15
Benito MB, Navarro M, Vidal F, Gaspar-Escribano J, García-Rodríguez MJ, Martínez-Solares JM (2010) A new seismic hazard assessment in the region of Andalusia (Southern Spain). Bull Earthquake Eng 8(4):739-766

Bommer JJ, Stafford PJ, Alarcón JE, Akkar S (2007) The influence of magnitude range on empirical ground-motion prediction. Bull Seismol Soc Am 97(6):2152-2170

Boore DM (2004) Estimating Vs(30) (or NEHRP site classes) from shallow velocity models (depths $<30 \mathrm{~m}$ ). Bull Seismol Soc Am 94(2):591-597

Boore DM, Thompson EM, Cadet H (2011) Regional correlations of VS 30 and velocities averaged over depths less than and greater than 30 meters. Bull Seismol Soc Am 101(6):3046-3059

Booth E (2007) The estimation of peak ground-motion parameters from spectral ordinates. J Earthq Eng 11:13-32

Borcherdt R, Wentworth CM, Janssen A, Fumal T, Gibbs J (1991) Methodology for predictive GIS mapping of special study zones for strong ground shaking in the San Francisco Bay region, California, in: 4th Int. Conf. Seismic Zonation. pp. 545-552

Buforn E, López-Sánchez C, Lozano L, Martínez-Solares JM, Cesca S, Oliveira CS, Udías A (2019) Re-evaluation of seismic intensities and relocation of 1969 Saint Vincent Cape seismic sequence: a comparison with the 1755 Lisbon earthquake. Pure and Applied Geophysics, 1-20

Buforn E, Bezzeghoud M, UdÍas A, Pro C (2004) Seismic sources on the Iberia-African plate boundary and their tectonic implications. Pure Appl Geophys 161:623-646. https://doi.org/10.1007/ s00024-003-2466-1

Casado CL, Palacios SM, Delgado J, Peláez JA (2000) Attenuation of intensity with epicentral distance in the Iberian Peninsula. Bull Seismol Soc Am 90(1):34-47

Chilès JP, Desassis N (2018) Fifty years of Kriging. In: Daya SB, Cheng Q, Agterberg F (eds) Handbook of Mathematical Geosciences. Springer, Cham ISBN978-3-319-78998-9

Choi Y, Stewart JP (2005) Nonlinear site amplification as function of $30 \mathrm{~m}$ shear wave velocity. Earthquake Spectra 21(1):1-30

Coburn A, Spence R, Pomonis A (1992) Factors determining human casualty levels in earthquakes: mortality prediction in building collapse. X World Conf. on Earthquake Eng, Madrid, pp 19-24

DBPPCRS (1995) Directriz básica de planificación de protección civil ante el riesgo sísmico Boletín Oficial del Estado 124, 1529415304. (In Spanish)

DBPPCRS (2004) Directriz básica de planificación de protección civil ante el riesgo sísmico Boletín Oficial del Estado 238, 3320533208. (In Spanish)

Deif A, El-Hussain I, Al-Jabri K, Toksoz N, El-Hady S, Al-Hashmi S, Al-Saifi M (2013) Deterministic seismic hazard assessment for Sultanate of Oman. Arabian Jour Geosc 6(12):4947-4960

Del Gaudio V, Pierri P, Venisti N (2019) Site classification of Italian accelerometric stations from cluster analysis of residuals of peak ground motion data regressions. Sci Total Environ 681:39-55

Dong L, Tong X, Ma J (2020) Quantitative investigation of tomographic effects in abnormal regions of complex structures. Elsevier Eng. https://doi.org/10.1016/j.eng.2020.06.021

Douglas R (2014) Integrating natural disaster risks and resilience into the financial system. Willis Research Network. Concept Note, London

ESRI - Environmental Systems Research Institute (2020) Optimized hot spot analysis. Available at: https://desktop.arcgis.com/en/arcmap/10.5/tools/spatial-statistics-toolbox/optimized-hot-spot-analy sis.htm (Jun 2020)

García Blanco RM (2009) Caracterización del potencial sísmico y su influencia en la determinación de la peligrosidad sísmica probabilista. PhD Thesis. Polythecnical University of Madrid (in Spanish)

García-Mayordomo J (2015) Creación de un modelo de zonas sismogénicas para el cálculo del mapa de peligrosidad sísmica de España. Serie Riesgos Geológicos/Geotecnia, 5. Instituto Geológico y Minero de España, Madrid 
Garrido J, Gutiérrez ML (2015) Andalusian cultural heritage and natural hazards prevention. In: Engineering Geology for Society and Territory, vol 8. Springer, Cham, pp 437-440

Gaspar-Escribano JM, Benito B (2008) Overview of recent seismic risk analyses in Spain. In: 14 World Conference on Earthquake Engineering. Beiijng, 12-19 October 2008. 10pp

Gaspar-Escribano JM, Benito B (2007) Ground-motion characterization of low-to-moderate seismicity zones and implications for seismic design: lessons from recent $\mathrm{M} \mathrm{w} \sim 4.8$ damaging earthquakes in southeast Spain. Bull Seismol Soc Am 97(2):531-544

Gaspar-Escribano, JM, Rivas-Medina A, Benito B, Torres Y, Quirós LE, Murphy P (2008) Seismic vulnerability and damage assessment in Navarre (NE Spain). Informe final proyecto RISNA. Evaluación del Riesgo Sísmico en Navarra. Volumen 2: Evaluación de la vulnerabilidad sísmica. 63 pp. (In Spanish)

Giovinazzi S, Lagomarsino S (2004) A macroseismic method for the vulnerability assessment of buildings. 13th World Conference on Earthquake Engineering, Vancouver, B.C.

Gould N (2003) Understanding the language of seismic risk analysis. IMRI Expert Commentary. Available: /www.irmi.com/artic les/expert-commentary/understanding-the-language-of-seism ic-risk-analysis

Govantes PG (1984) El riesgo sísmico de Sevilla. Doctoral dissertation, Univ. de Sevilla. (In Spanish)

Grasso S, Maugeri M (2012) The seismic microzonation of the city of Catania (Italy) for the Etna scenario earthquake $(M=6.2)$ of February 20, 1818. Earthquake Spectra 28(2):573-594

Grimison NL, Chen WP (1986) The Azores-Gibraltar plate boundary: focal mechanisms, depths of earthquakes, and their tectonic implications. J Geoph Research: Solid Earth 91(B2):2029-2047

Grünthal G (1998) European macroseismic scale (1998). Centre Européen de Géodynamique et de Séismologie, Luxembourg

Grünthal G, Wahlström R (2012) The European-Mediterranean earthquake catalogue (EMEC) for the last millennium. J Seismol 16(3):535-570

Hosseinpour V, Saeidi A, Nollet MJ, Nastev M (2021) Seismic loss estimation software: a comprehensive review of risk assessment steps, software development and limitations. Eng Struct 232:111866

IGME- Instituto Geológico y Minero de España (1986) Mapa Geotécnico y de Riesgos Geológicos de la ciudad de Sevilla. Scale $1: 25000$

IGME-Instituto Geológico y Minero de España (1990) Mapa geotécnico para la Ordenación Territorial y Urbana de Sevilla. Scale $1: 25000$

IGN-Instituto Geográfico Nacional (2020) Instituto Geográfico Nacional Seismic Catalogue

IGN-Instituto Geográfico Nacional-UPM Working Group (2013) Actualización de mapas de peligrosidad sísmica en España 2012. Instituto Geográfico Nacional, Madrid (in Spanish)

Imai T (1981) P-and s-wave velocities of the ground in Japan. Prc. 9th ISCMFE. Tokyo 2:257-260

Instituto Nacional de Estadística - INE (2012) Censos de población, en Base de datos elec- trónica INEbase: Demografía y población: Cifras de población y censos demográficos. Availabe in: https://www.ine.es/censos2011_datos/cen11_datos_resul tados_seccen.htm (Jun 2020)

Jaramillo A, Huete R, Rodríguez C, Suárez L, Sanz V (2005) Anejo I.2 Mapa Geotécnico Básico de la Ciudad de Sevilla. Protocolo de Inspección Técnica de Edificaciones, Col. Of. de Arquit, Sevilla

Jaramillo CR (2009) Do natural disasters have long-term effects on growth?. Doc. CEDE, (2009-24)

Joyner WB, Fumal TE (1984) Use of measured shear-wave velocity for predicting geologic site effects on strong ground motion, in: 8th World Conf. on Earthq. Eng. pp. 777-783
Julià PB, Ferreira TM (2021) From single-to multi-hazard vulnerability and risk in Historic Urban Areas: a literature review. Natural Hazards, 1-36

Kramer SL (1996) Geotechnical earthquake engineering. Pearson Education India

Kunreuther H (1996) Mitigating disaster losses through insurance, J. Risk Uncertainty 12(2/3):17

Lantada N, Irizarry J, Barbat AH, Goula X, Roca A, Susagna T, Pujades LG (2010) Seismic hazard and risk scenarios for Barcelona, Spain, using the risk-UE vulnerability index method. Bull Earthquake Eng 8(2):201-229

Le Goff B, Bezzeghoud M, Borges JF, Fitzenz D (2013) Optimal representation of our knowledge about seismic sources for PSHA in low deformation areas

Ma J, Dong L, Zhao G, Li X (2019) Ground motions induced by mining seismic events with different focal mechanisms. Int J Rock Mech Mining Sci 116:99-110

Martínez Solares JM, Cabañas L, Benito B, Ricas A, Gaspar JM, Ruíz S, Rodríguez O (2013) Actualización de mapas de peligrosidad sísmica de España 2012. CNIG, Madrid

Mazo CO, Arozamena P, Mendaña F, Álvarez R (2009) Geotechnical problems during the soil boring in the Seville underground (Spain). In Proceedings of the 17th International Conference on Soil Mechanics and Geotechnical Engineering (Volumes 1, 2, 3 and 4) (pp. 2461-2464). IOS Press

Mezcua J, García Blanco RM, Rueda J (2008) On the strong ground motion attenuation in Spain. Bull Seism Soc Am 98:1342-1353

Midorikawa S (1987) Prediction of isoseismal map in the Kanto plain due to hypothetical earthquake. J Struct Eng 33B:43-48

Martınez-Solares, J. M., \& Mezcua, J. (2002). Catálogo sısmico de la Penınsula Ibérica (880 aC-1900). Instituto Geográfico NacionalMonografia, (18), 444

Molina-Palacios S, Agea-Medina N, Galiana-Merino JJ, Navarro Bernal M, Huesca Tortosa JA, García-Jerez A et al (2019a) Seismic damage scenarios in the municipalities of Elche and Alicante (Spain). A first step to the emergency planning. Int J Safety Security Eng 9(3):237-248

Molina-Palacios S, Agea-Medina N, Galiana-Merino JJ, Navarro Bernal M, Huesca Tortosa JA, García-Jerez A et al (2019b) Seismic damage scenarios in the municipalities of Elche and Alicante (Spain). A first step to the emergency planning. Int J Safety Secur Eng 9(3):237-248. https://doi.org/10.2495/SAFE-V9-N3-237-248

Mostafa SI, Abdelhafiez HE (2019) Deterministic scenarios for seismic hazard assessment in Egypt. J African Earth Sci 160:103655

MV101 (1963) Norma M.V.101-1962 Acciones en la edificación, Ministerio de la Vivienda, decreto de 17 de enero de 1963 (195/1963). (In Spanish)

NCSE-02 (2002) Norma de Construcción Sismorresistente, Parte General y de Edificación, Comisión Permanente de Normas Sismorresistente, Real Decreto 997/2002 del 27 de septiembre de 2002, Boletín Oficial del Estado, 244, viernes 11 de 0ctubre de 2002. 35898-35967. (In Spanish)

Pérez-Santisteban I, Martin AM, Carbó A, Ruiz-Fonticiella JM (2016) Empirical correlation of shear wave velocity (vs) with SPT of soils in Madrid. In Near Surface Geoscience 2016-22nd European Meeting of Environmental and Engineering Geophysics (Vol 2016, No. 1, pp. cp-495)

Peruzzi G, Albarello D, Baglione M, D'Intinosante V, Fabbroni P, Pileggi D (2016) Assessing 1D litho-stratigraphical amplification factor for microzoning studies in Italy. Bull Earthq Eng 14(2):373-389

PGS-1 (1968) Part A. Government Presidency. BOE 30:1969/02/04, 1658-1675. (In Spanish)

Quirós L (2017) Modelizaciones y análisis de sensibilidad en la evaluación integral del riesgo sísmico a escala urbana. $\mathrm{PhD}$ Thesis. Universidad Politécnica de Madrid. (In Spanish) 
Roldán García FJ, Borrero Domínguez J. (1988) Mapa Geológico de España 1:50.000 MAGNA. Hoja n ${ }^{\circ}$ 985, Carmona. Instituto Geológico y Minero de España (eds), Madrid

Re M (2000) Natural catastrophes, current position, special issue. Munich Reinsurance Co., Munich

Rehman F, El-Hady SM, Atef AH, Harbi HM (2016) Seismic hazard assessment of western coastal province of Saudi Arabia: deterministic approach. Earthquake Sci 29(5):299-309

Ruiz-Constán A, Ruiz-Armenteros AM, Galindo-Zaldívar J, LamasFernández F, Sousa JJ, Sanz de Galdeano C et al (2017) Factors determining subsidence in urbanized floodplains: evidence from MTInSAR in Seville. Earth Surface Processes Landforms 42(14):2484-2497

Salgado-Gálvez MA, Cardona OD, Carreño ML, Barbat AH (2015) Probabilistic seismic hazard and risk assessment in Spain. Monograph Series in Earthquake Engineering, ed. AH Barbat

Silva V, Crowley H, Varum H, Pinho R (2015) Seismic risk assessment for mainland Portugal. Bull Earthquake Eng 13(2):429-457

Sousa ML, Carvalho A, Bilé Serra J, Mateus M, Martins A(2008) Estudo do risco sísmico e de tsunamis do Algarve (ERSTA), Relatório final. LNEC tec. report 295/2008, Lisbon, 1-85. (In Portuguese)

Spence R, So E, Jenny S, Castella H, Ewald M, Booth E (2008) The global earthquake vulnerability estimation system (GEVES): an approach for earthquake risk assessment for insurance applications. Bull Earthq Eng 6:463-483

Stewart JP, Douglas J, Javanbarg M, Bozorgnia Y, Abrahamson N, Boore D, Campbell K, Delavaud E, Erdik M, Stafford P (2015) Selection of ground motion prediction equations for the global earthquake model. Earthquake Spectra 31(1):19-45
Stewart JP, Choi Y, Graves RW (2005) Empirical characterization of site conditions on strong ground motion. University of California, Berkeley

Tezcan S, Ozdemir Z (2011) A refined formula for the allowable soil pressure using shear wave velocities. Open Civil Eng J 5(1)

United Nations. International Strategy for Disaster Reduction. Secretariat. (2015) Global assessment report on DRR 2015: making development sustainable: the future of disaster risk management. UN

Vilanova SP, Fonseca JF (2007) Probabilistic seismic-hazard assessment for Portugal. Bull Seismol Soc Am 97(5):1702-1717

Vilanova SP, Fonseca JF (2004) Seismic hazard impact of the Lower Tagus Valley Fault Zone (SW Iberia). J Seismol 8:331-345. https://doi.org/10.1023/B:JOSE.0000038457.01879.b0

Villamor Pérez MP, Stirling MW, Tsige Aga M, Berryman KR, Martínez Díaz JJ, Martín-González F (2012) Contribution of active faults in the intraplate area of Iberia to seismic hazard: The Alentejo-Plasencia Fault. J Iberian Geol 38(1):85-111

Wang JP, Huang D, Yang Z (2012) Deterministic seismic hazard map for Taiwan developed using an in-house Excel-based program. Comput Geosci 48:111-116

Zadehmohamad M (2020) Evaluation of cyclic displacement amplitude of integral bridge abutment on backfill soil pressure and settlements. J Transport Res 